\title{
Impacts of groundwater over exploitation on the renewal and hydrodynamic behavior of the alluvial aquifer of Sidi Bel Abbes (Algerian NW)
}

\author{
Abdelkader Otmane ${ }^{1,2}$ (D) Kamila Baba-Hamed ${ }^{2} \cdot$ Abderrazak Bouanani $^{2} \cdot$ Radia Gherissi $^{2,3}$
}

Received: 29 September 2020 / Accepted: 8 March 2021 / Published online: 25 March 2021

(c) The Author(s) 2021

\begin{abstract}
Sidi Bel Abbes plain, in Western Algeria, covers an area of $813 \mathrm{~km}^{2}$ and holds an important groundwater reservoir, providing the region with a large water potential. It displays characteristics of a peri-urban aquifer, with a large agricultural sector. The climatic variations that affected this region, the development of industrial and agricultural activities along with the over-exploitation of the groundwater resource negatively impact the aquifer's hydrodynamic balance. This work is structured around a multiapproach process based mainly on geophysical data to determine the reservoir bathymetry, rainfall data, humidity data using the standardized precipitation index (SPI), piezometric maps, hydrodynamic data, and groundwater extraction rate. Results revealed a significant decrease in humidity values over time. This negatively influences the water potential of the alluvial aquifer and induces a lateral recharge from adjacent aquifers (overfilling). Indeed, the rainfall contribution to the recharge appears low compared to that of the surrounding aquifers. However, total annual rainfall above $500 \mathrm{~mm} / \mathrm{year}$ may reduce the input of the adjacent aquifers. Besides, our study indicates a well-defined hydrodynamic pattern in the alluvial aquifer, due to the bowl-shaped bedrock of the aquifer and the excessive overexploitation, especially downstream (the region of Sidi Bel Abbes). Thus, this aquifer adapted to such exploitation, through continuous and systematic recharge of drainage flows by the upstream groundwater (regions characterized by a wall uplift). The aquifer's pluviometric dependence occurs clearly in its south-western part. A 50\% humidity value implies a $0-10 \mathrm{~m}$ increase in the water table.
\end{abstract}

Keywords Alluvial aquifer $\cdot$ Sidi Bel Abbes $\cdot$ Overexploitation $\cdot$ Hydrodynamics $\cdot$ Humidity $\cdot$ Spatio-temporal

\section{Introduction}

Abdelkader Otmane

otmanekadeur@outlook.fr

Kamila Baba-Hamed

kambabahamed@yahoo.fr

Abderrazak Bouanani

a_bouananidz@yahoo.fr

Radia Gherissi

hydro_rad@yahoo.fr

1 Faculty of Natural Sciences and Life, Ibn Khaldoun Tiaret University, BP 14000, KarmanTiaret, Algeria

2 Laboratory 25: Water and Soil Resources, Science and Technology Faculty, University of Tlemcen, Chetouane, BP 230, 13000 Tlemcen, Algeria

3 Science and Technology Faculty, University Centre of Maghnia, Maghnia, BP 13300, Tlemcen, Algeria
Climate changes affecting the world today impact on a global scale (Solomon et al. 2007; Lespinas 2008; Loehle and Scafetta 2012 2012; Scafetta 2012; Loehle 2014) and regional scales (Faye et al. 2015).

According to the Intergovernmental Panel on Climate Change (IPCC), this phenomenon can lead to long drought periods. As an example, the drought experienced in West Africa since the 1970s (Sircoulon 1976). Many studies already recorded water resource depletion indicating a drier period in large parts of the world in the future (Vörösmarty et al. 2000; Mirchi et al. 2013; Steinschneider et al. 2015).

However, the increase in global water demand combined with the unsustainable development in some regions has considerably increased the anthropogenic risk on water resources (Gain and Giupponi 2015) and put almost a third of the world's population at threat of water scarcity (Vörösmarty et al. 2010). Future forecasts predict that at 
least $40 \%$ of the world's population will face substantial challenges in accessing clean water for domestic and agricultural use (Gleick 2003).

At the regional scale, Mediterranean areas are experiencing unprecedented climatic variations, marked by declining rainfall patterns (Xoplaki et al. 2004; Cudennec et al. 2007; Nassopoulos 2012). Algeria, a southern Mediterranean country, faces a severe water shortage caused by low precipitation and drought periods, worsening year after year, and coupled with continuously increasing water needs. Many studies provide clear indications to this effect (Meddi et al. 2009; Ghenim and Megnounif 2013; Nouaceur et al. 2013; El Mahi et al. 2014; Gherissi 2018; Otmane et al. 2018).

Confronted with this surface water resources scarcity, countries around the world turned to groundwater, putting this resource at great pressure. In Northern Algeria, for example, average aquifer exploitation was estimated at $80 \%$ in 2002 (Boudjadja et al. 2003).

Under these circumstances, northwestern Algeria and particularly the alluvial aquifer in the Plio-quaternary of Sidi Bel Abbès is not spared from this exploitation. The Water Resources Department of Sidi Bel Abbes estimates the alluvial aquifer capacity in 2011 at $10.65 \mathrm{hm}^{3}$, and the annual exploitation volume, for drinking water supply (AEP) only, was about $5.0 \mathrm{hm}^{3} /$ year and the rest was used for irrigation. The aquifer low water potential is affected by significant piezometric declines since the early 1970s.

Studies on adjusting groundwater exploitation of the Sidi Bel Abbes alluvial aquifer according to the recharge rates and hydrodynamic conditions remain limited: nevertheless, works of Sourisseau (1972); Megherfi (2010); Yousfi (2008); Abtout (2013) and Bellaredj (2019) are worth mentioning.

To improve this aquifer's management, it is necessary to understand its spatial and temporal evolution since the $70 \mathrm{~s}$ and adopt a strategy compliant with the multi-risks that the region has experienced (drought, increasing water needs...). It is in this context that our research has been carried out.

\section{Presentation of the study area}

The subject of our study is the alluvial aquifer of Sidi Bel Abbes plain, northwest of Algeria (Fig. 1a), at latitudes $34^{\circ} 86^{\prime}$ and $35^{\circ} 22^{\prime}$ north and longitudes $0^{\circ} 94^{\prime}$ and $0^{\circ} 32^{\prime}$ west. It is part of the sub-catchment basin of the Mekerra downstream, between the Sidi Ali Ben Youb cluse and the Rock's edge downstream of Sidi Bel Abbes. Geographically, the study region is limited by the Tessala Mountains to the north, the tabular massif of Tlemcen and Saida to the south, the basin of the Isser wadi to the west, and the Mountains of Béni Chougrane and Bouhanifia to the east. Mekerra Wadi crosses Sidi Bel Abbes plain from south to north for about $50 \mathrm{~km}$ (Fig. 1b).
The plio-quaternary alluvial aquifer covers $69 \%$ $\left(813.4 \mathrm{~km}^{2}\right)$ of the plain's total surface area $\left(1180.5 \mathrm{~km}^{2}\right)$. It is a large basin with clayey-marly bedrock dating back to the Miocene and Lower Pliocene and filled with quaternary alluvial deposits, mainly conglomeratic with sandy and gritty deposits alternating with silts, created by the disintegration at the edges of the relief. The alluvial aquifer is limited by several hydrogeologic units, the most important of which are (Fig. 1a):

- Eocènes limestones of Sidi Ali Boussidi in the north (les Monts de Tessala)

- Jurassico-cretaceous limestones and dolomites of Sidi Ali Benyoub in the south (the Tlemcen-Saïda Mountains)

- Pliocene sandstone from the forest of Ténira in the east.

The study area is characterized by a plain climate with drier, warmer, and relatively high thermal variations (Otmane et al. 2018).

\section{Data}

\section{Rainfall data}

All the data were provided by the National Meteorological Office of Oran (O.N.M), and the National Agency of Hydraulic Resources (A.N.R.H).

The rainfall data in Sidi Bel Abbbes' plain are collected at six (6) stations (Table 1; Figs. 2 and 3).

Data needs to meet two important criteria: length of the observation period (covering as much time as possible) and quality (minimum missing data).

An inventory of the missing data per year and per station is presented in Fig. 2.

To avoid significant data deficiencies, we decided to start the series from the 1971/1972 hydrological year and end with the 2009/2010 year for each station. A total of 6 stations were selected (Fig. 3). They provide 39 years of data series with a good spatial distribution. Data sets were homogenized using the double-cumulation method and the gaps bridged by linear regressions between neighboring stations.

\section{The statistical method used to fill the missing data}

The observation series (1971-2010) presents a few missing data at the monthly and therefore annual scale (Fig. 2). The missing data were filled in using the simple linear regression method. This method neglects the geographical context and the local precipitation variations, leading to biases in judgment. To minimize these errors, the climatic conditions at each station were taken into account. The stations that best correspond to each other (linear correlation) were 


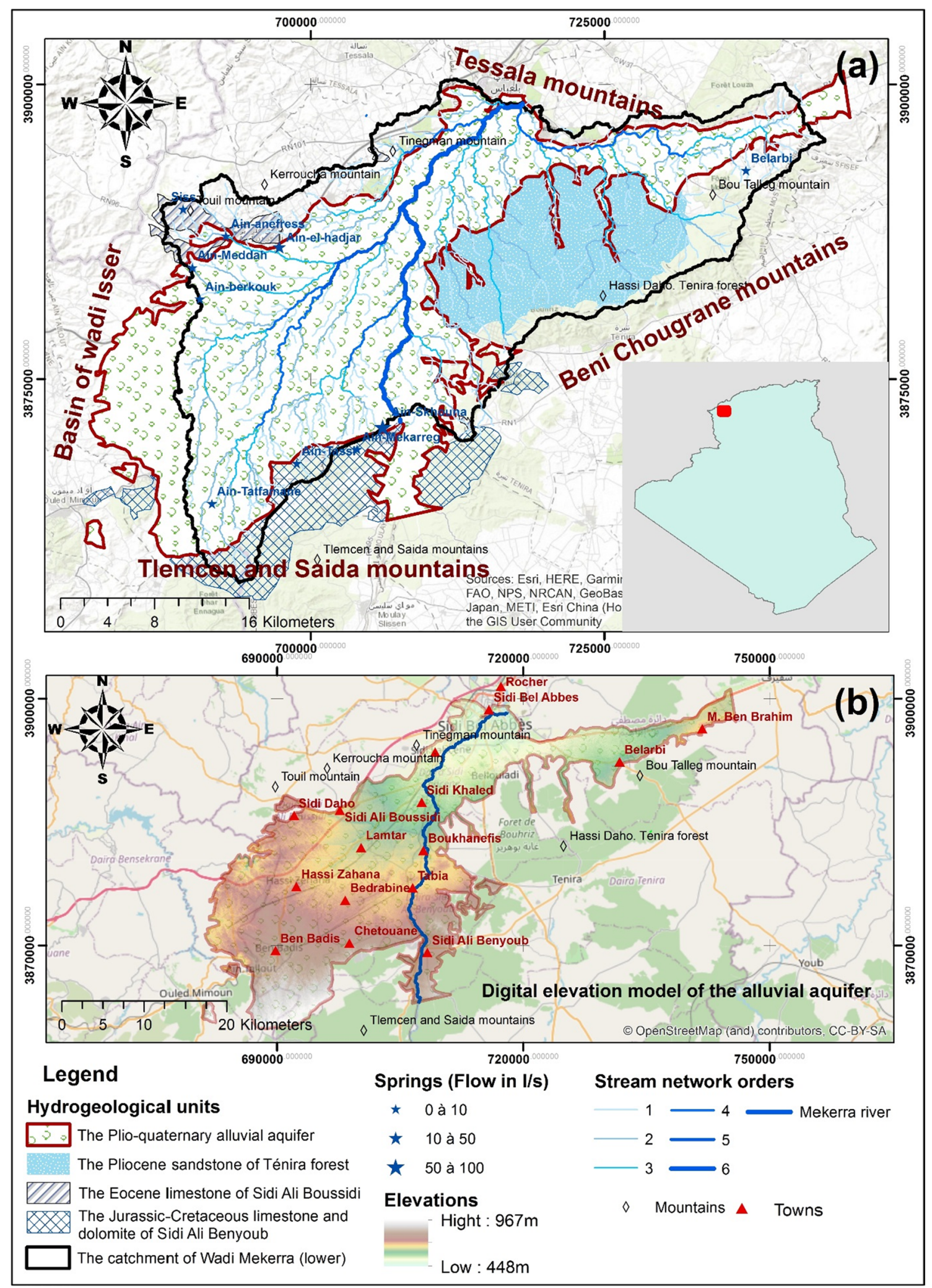

Fig. 1 Location, hydrogeology, and relief of the Lower Mekerra Basin 
Table 1 Rainfall station parameters

\begin{tabular}{llllll}
\hline Code & Name & Elevation $(\mathrm{m})$ & \multicolumn{2}{l}{ Coordinates $(\mathrm{km})$} & \multirow{2}{*}{ Operating period } \\
\cline { 4 - 5 } & & & $X$ & $Y$ & \\
\hline 110201 & Sidi Ali Ben Youb & 635 & 186.500 & 192.200 & $1913-2009$ \\
110305 & Sidi Bel Abbes & 485 & 194.250 & 215.600 & $1918-2009$ \\
110310 & Lamtar & 576 & 181.400 & 203.000 & $1942-2009$ \\
110314 & AïnTrid & 530 & 193.050 & 226.100 & $1942-2009$ \\
110507 & Chabrier & 755 & 194.800 & 190.450 & $1973-2009$ \\
110334 & Chetouane & 679 & 175.300 & 191.250 & $1977-2009$ \\
\hline
\end{tabular}

Fig. 2 Record of missing data by station and year

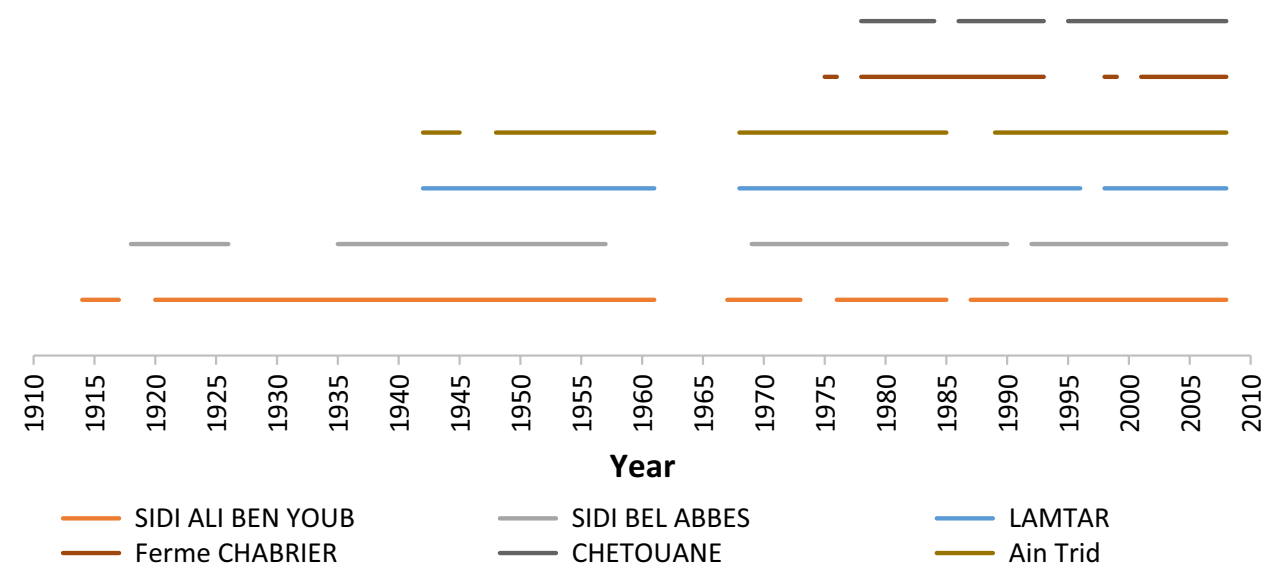

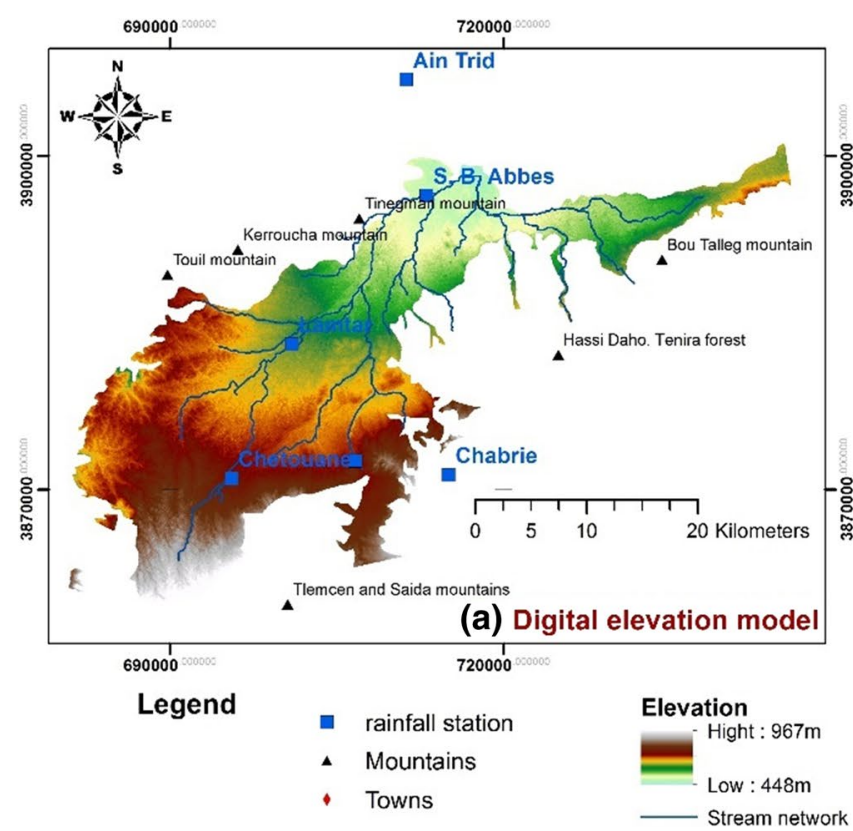

Fig. 3 Spatial distribution of precipitation over the 1971-2010 period

grouped together according to the weighting of the correlation coefficient value for each month of the year (Laborde 2007). In general, this method is performed by computing a simple linear regression between the monthly series to be

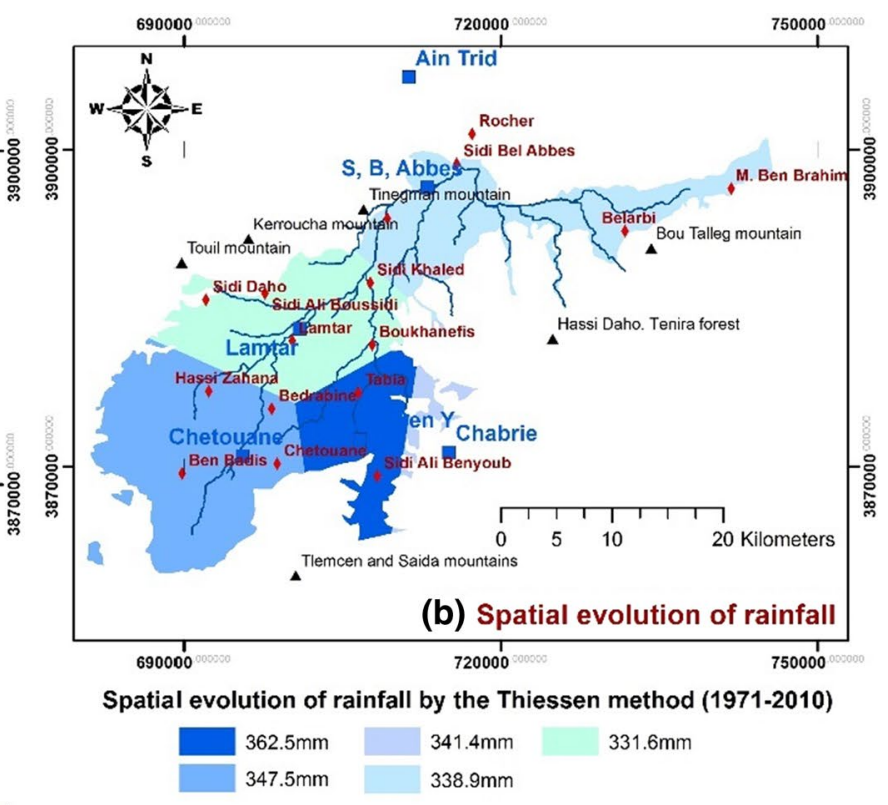

reconstructed and the complete monthly series of surrounding stations: $X$ and $Y$, the two compared stations, $x(i)$ and $y(i)$ their observations, with $X$ being the complete long-term 
station whose abundant information (size $n$ ) must complete the shorter information on $Y$.

The procedure consists in creating a graph $y(x)$ to provide insight into the bonding strength. If the scatter plot is elongated with low scatter around a central line, graphical adjustment of the latter is possible. Thus, the correlation coefficient can be calculated by:

$r_{x y}=\frac{\sum\left[\left(x(i)-m_{x}\right)\left(y(i)-m_{y}\right)\right]}{(k-1)\left(\delta_{x} \cdot \delta_{y}\right)}$

With $k$ number of values (couples) of the sample, concomitant of $x$ and $y ; m_{x}$ : average of $x=\left(\sum x(i)\right) / k ; m_{y}$ : average of $y=\left(\sum y(i)\right) / k ; \quad \delta_{x}$ : standard deviation of $x=\sqrt{\frac{\sum\left(x(i)-m_{x}\right)^{2}}{k-1}} ; \quad \delta_{y}:$ standard deviation of $y=\sqrt{\frac{\sum\left(y(i)-m_{y}\right)^{2}}{k-1}}$.

If the correlation is significant, the equation of the regression line can be written as:

$y(x)=m_{y}+r_{x y} \cdot \frac{\delta_{y}}{\delta_{x}} \cdot\left(x-m_{x}\right) \quad$ Or $\quad \ll y(x)=a x+b \gg$

with $a=r_{x y} \cdot \frac{\delta_{y}}{\delta_{x}}$ and $b=m_{y}-m_{x} \cdot r_{x y} \frac{\delta_{y}}{\delta_{x}}$.

Finally, using the regression line above [Eq. (2)], we calculate month by month the missing data from the different stations used in this study.

\section{Piezometric data}

Since 1971, the ANRH conducted some piezometric surveys to monitor Sidi Bel Abbes' alluvial aquifer. In this study, we have selected piezometric maps established in September for 1971, 1983, 1996, and 2010. The establishment of the maps is based on the readings of 20 water points well distributed in the region (Fig. 4).

These piezometric readings were adopted in order to assess as much as possible the fluctuation of the water table for each decade $(70,80,90$ and 2010) in the same month (high water). In addition, this choice arises to study the impact of climate variability on groundwater, especially as the majority of scientific research in the region has shown the climatic particularity of each decade (El Mahi et al. 2014; Gherissi 2018).

\section{Geomorphological data of the aquifer}

The thickness map of the Plio-Quaternary alluvial aquifer (Fig. 5a) was obtained from geo-electrical profiles performed by the CGG in 1970 (Compagnie Générale de Géophysique). The bedrock morphometric map was extracted with an ASTER (Advanced Spaceborne Thermal Emission and Reflection Radiometer) digital terrain model (Fig. 5b) with a spatial resolution of $30 \mathrm{~m}$, while the bathymetric map (Fig. 5a) is based on a GIS (Geographic information system).

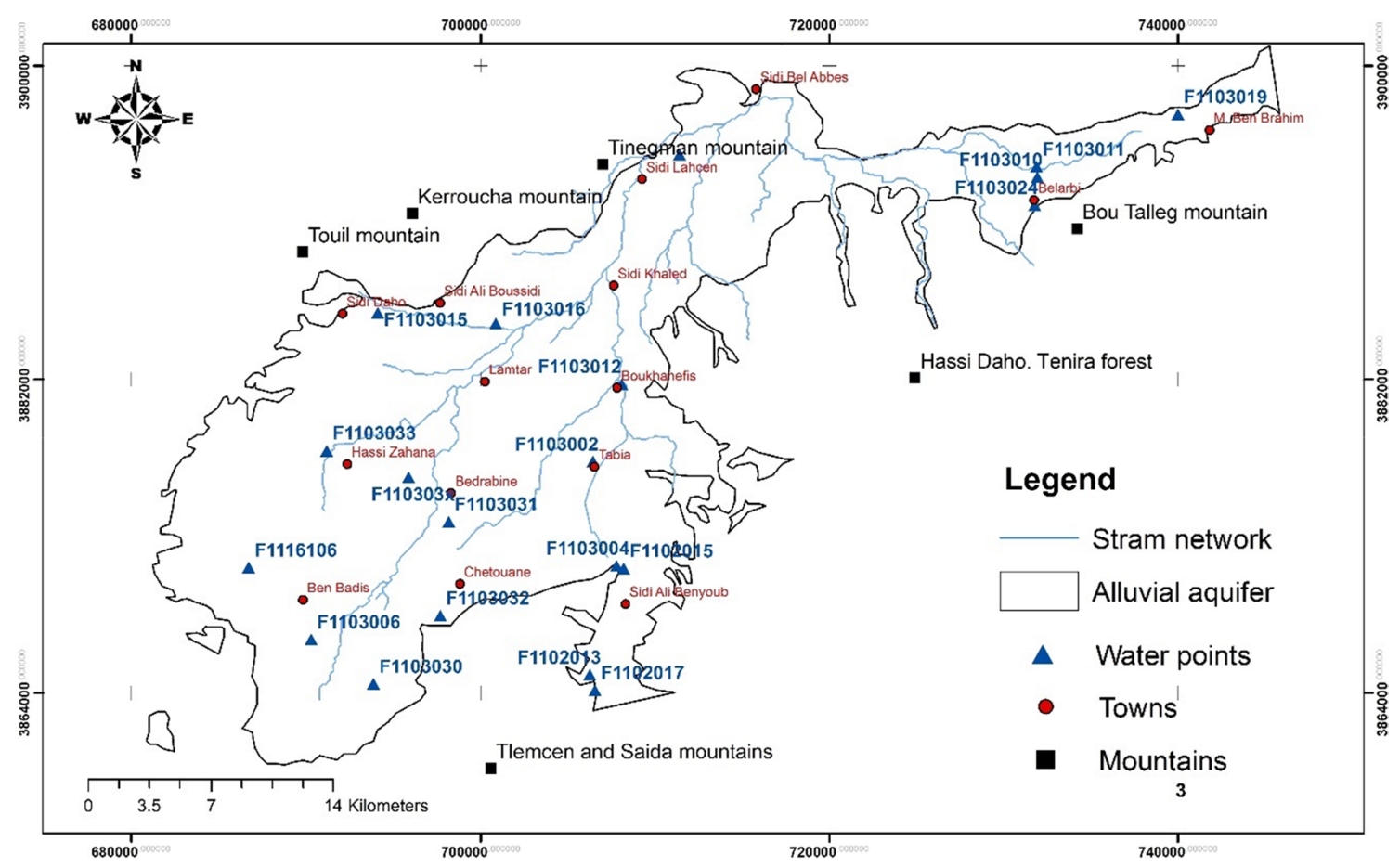

Fig. 4 Spatial distribution of water points 


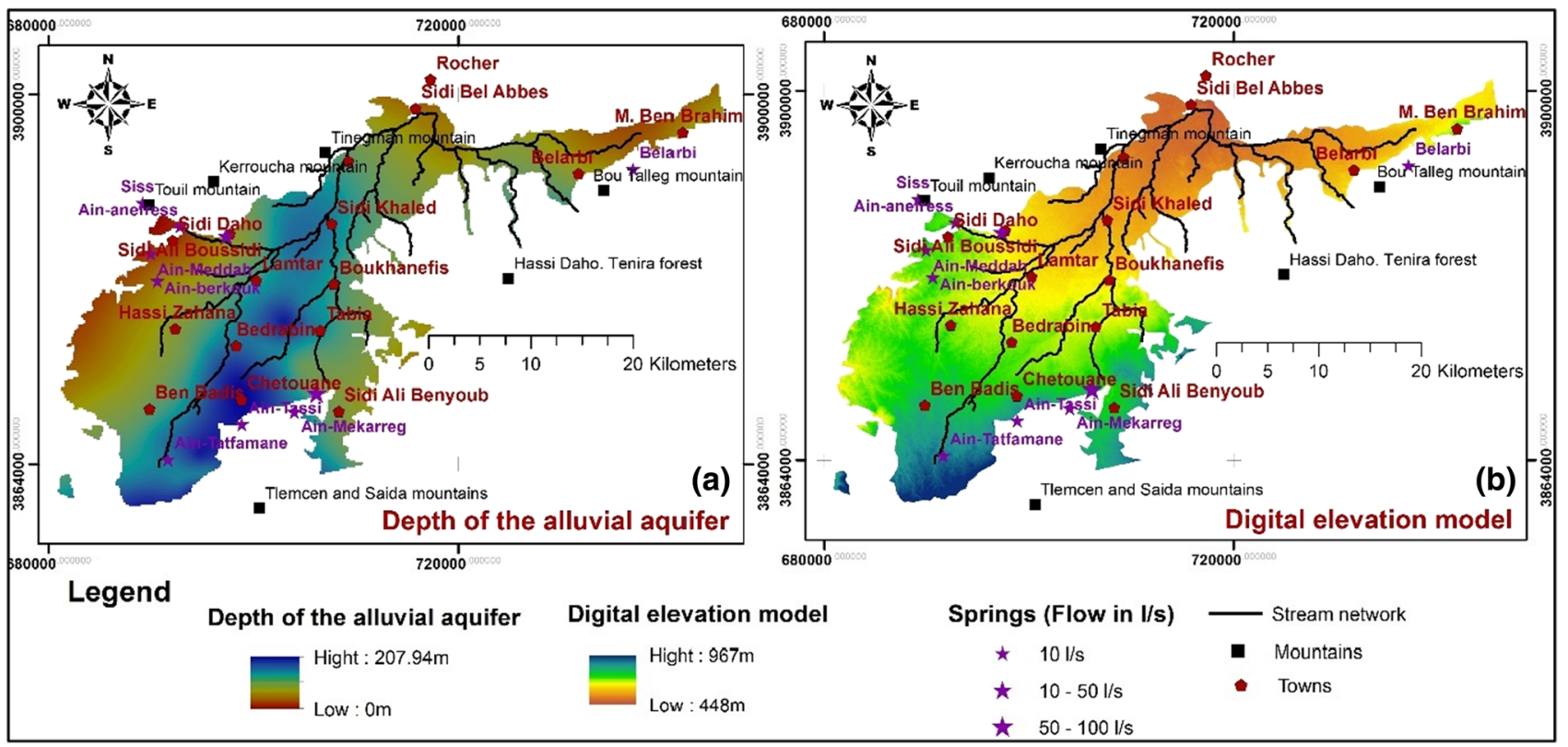

Fig. 5 Digital elevation model and aquifer thickness

\section{Aquifer exploitation data}

This study is based on the litho-stratigraphic records of wells established by the "Direction des Ressources en eau" (DRE) of Sidi Bel Abbes to select only water points that capture the alluvial aquifer (Fig. 6).

In fact, the set of exploitation data in water supply was provided by the water resources department (DRE) of Sidi Bel Abbes for 2011, indicating the groundwater extraction rate, with an annual volume of about $5 \mathrm{hm}^{3} /$ year (Fig. 6a). While the exploitation data for irrigation were provided by the ANRH.
It is important to note that water points intended for irrigation are concentrated mainly in the northern part of the aquifer (Fig. 6b).

\section{Methodology}

Our approach consists, first, in applying the standardized precipitation index (SPI) on selected data collected in the area of interest to determine the Spatio-temporal variations of humidity in Sidi Bel Abbes alluvial plain between 1971 and 2010. Then, based on the piezometric maps established

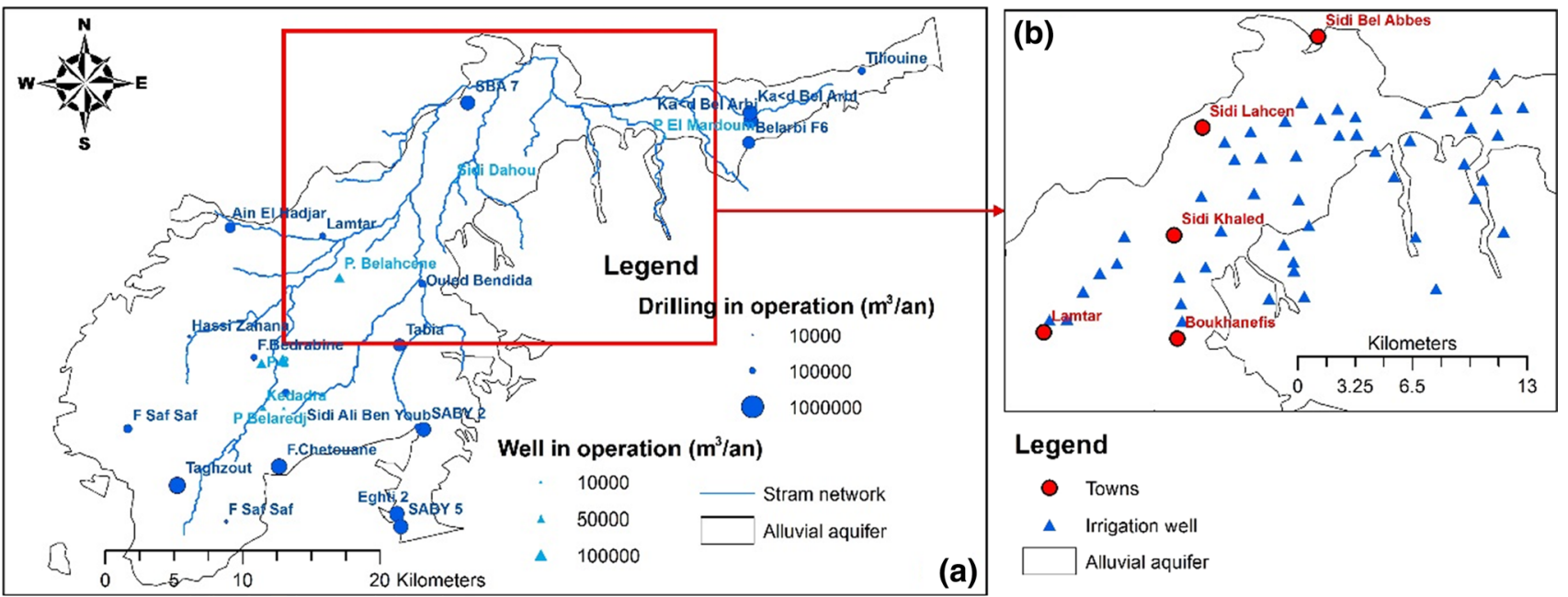

Fig. 6 Aquifer exploitation rate in the water supply (a), and irrigation (b) 
in September 1971, 1983, 1996, and 2010 by ANRH, we can determine the Spatio-temporal variations of the groundwater level fluctuation.

Finally, based on previously obtained results, we discuss the impact of the Spatio-temporal humidity variation on the hydrodynamic pattern of the alluvial aquifer, while considering its overexploitation and recharge.

\section{Standardized Precipitation Index}

McKee et al (1993) introduced the standardized precipitation index (SPI) in 1993 according to the following formula:

$\mathrm{SPI}=\frac{\left(X_{i}-X_{m}\right)}{S_{i}}$

where $X_{i}$ is the cumulative precipitation for a year $i ; X_{m}$ and $S_{i}$, are, respectively, the mean and standard deviation of the annual precipitation recorded over a given period.

This index defines the drought severity according to different classes (Table 2) (Bergaoui and Alouini 2002; ArdoinBardin et al. 2003; Ardoin-Bardin 2004; Ali and Lebel 2009). The negative annual values indicate a dry situation relative to the selected baseline period while the positive values indicate a humid situation.

The SPI tool was used by many authors in various regions of the world (Wu et al. 2001; Giddings et al. 2005; Sönmez et al. 2005; Bodian 2014).

The approach chosen in this section is first to determine the drought severity on a Spatio-temporal scale, based on the statistical parameters $\left(X_{m}\right.$ and $\left.S_{i}\right)$ over the entire observation period (1971-2010) (Appendix 1). Then, to study the hydrodynamic pattern of the aquifer during the various piezometric surveys available (September 1971, 1983, 1996, and 2010), the statistical parameters $\left(\mathrm{X}_{\mathrm{m}}\right.$ and $\left.\mathrm{S}_{\mathrm{i}}\right)$ of each period separately $(1971 / 1983,1983 / 1996$, and 1996/2010) are essential (Appendix 2). This is required for the determination of the spatial evolution of humidity during each

Table 2 Drought classification based on the standardized precipitation index $(\mathrm{SPI})$ value

\begin{tabular}{ll}
\hline SPI class & Drought severity \\
\hline SPI $>2$ & Extreme humidity \\
$1<$ SPI $<2$ & High humidity \\
$0<$ SPI $<1$ & Moderate humidity \\
$-1<$ SPI $<0$ & Moderate drought \\
$-2<$ SPI $<-1$ & Severe drought \\
SPI $<-2$ & Extreme drought \\
\hline
\end{tabular}

period.

\section{Results and discussion}

\section{Spatio-temporal evolution of humidity (1971-2010)}

Based on the dates of the piezometric readings adopted in this study, we divided the rainfall data series (SPI) into three sub-periods (Fig. 7).

The temporal evolution of SPI annual mean values at the six stations over the 1971-2010 period (Fig. 7), highlights many positive values early in the series. Then, precipitation deficits occur almost systematically until the end of the observation period.

Based on all stations and all years (72 cases for the period 1971-1983, 78 cases for 1983-1996 and 84 cases for 1996-2010). Humidity during the periods (1971-1983), (1983-1996) and (1996-2010) prevailed in more than 61, 37 , and 38\% of the cases, respectively (Table 3 and Appendix 1). For the 1996-2010 period, some cases of extreme humidity occur along with an increase in drought conditions (62\%). This is due to the climate change phenomenon affecting the region during the last decades (Talia et al. 2011; Otmane et al. 2019). Therefore, over the three considered periods from 1971 to 2010, the drought prevails significantly with time, accounting for $38 \%$ (1971-83) to $62 \%$ (1996-2010) of cases.

The spatial distribution of the average humidity values (the sum of moderate, high, and extreme humidity) during the entire observation period at the six stations (Fig. 8 and Appendix 1) reveals a significant humidity value of $80 \%$ in the western part of the plain between 1971 and 1983. This humidity has since then, and for the duration of the remaining observation series, gradually decreased to an alarming level, mainly during the $1996-2010$ period (10-20\%) (Fig. 8).

\section{Spatial evolution of humidity in each period}

The spatial distribution of humidity during each period in this study (Fig. 9 and Appendix 1) indicates a significant and even concerning spatial increase in low humidity values from north to south on the plain. The humidity value reaches $35 \%$ in the 1983-1996 period around Sidi Bel Abbes city, continuing to spread over half the study area in 1996-2010.

However, the 1971-1983 period is referred to as a transitional period (Breakthrough Period) (Ghenim et al. 2010) when the recorded humidity value was moderate, ranging from 45 to $50 \%$ across the whole plain. 

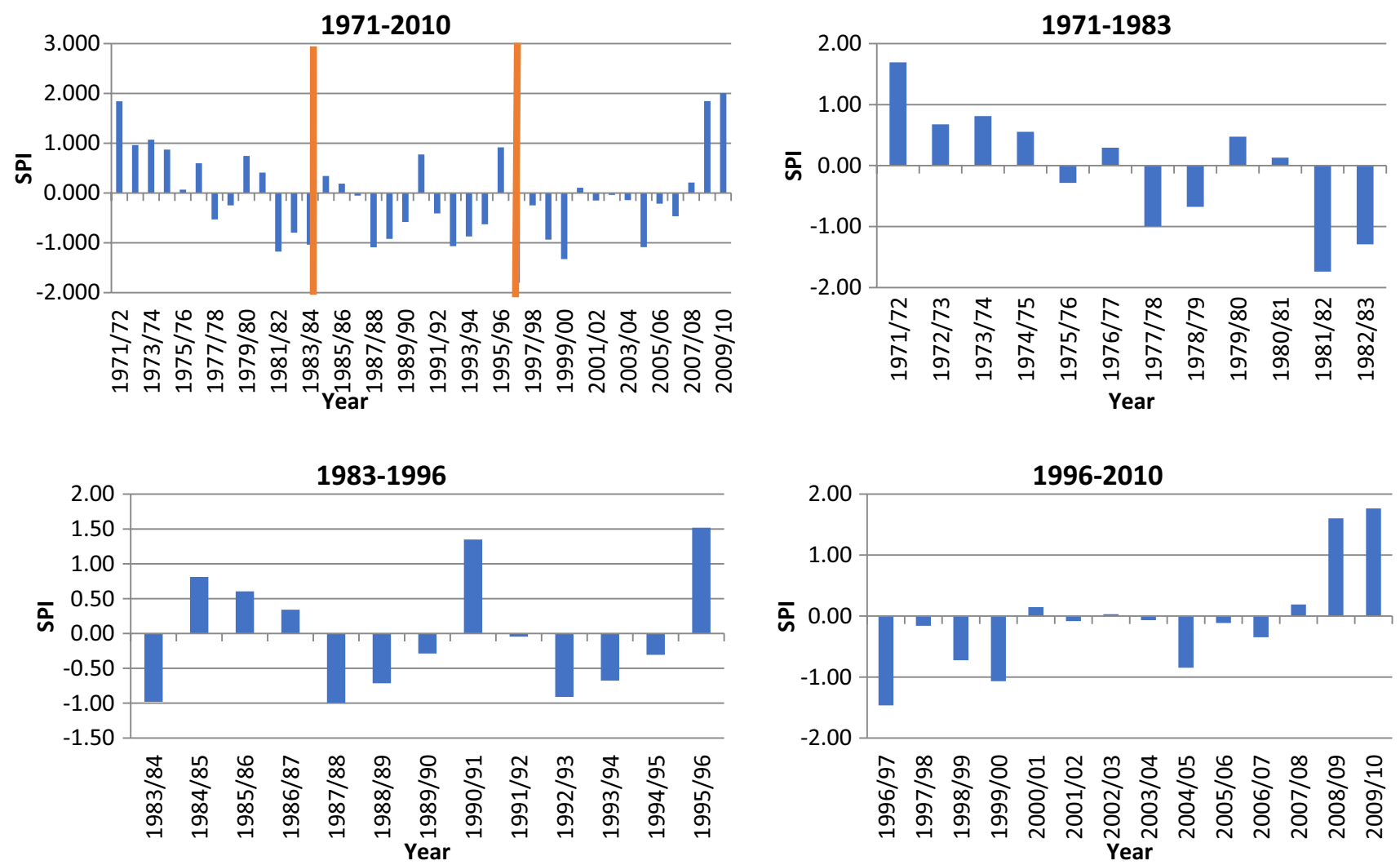

Fig. 7 Temporal evolution of SPI annual mean values at the six stations during the 1971-2010 period and the selected sub-periods

Table 3 Rates (in \%) of occurrence of climate conditions during the periods 1971-1983, 1983-1996, and 1996-2010, considering the whole series of observations

\begin{tabular}{|c|c|c|c|c|c|c|c|}
\hline & \multirow{2}{*}{$\begin{array}{l}\text { Descriptors } \\
\mathrm{P} \text { avg in } 6 \text { station }\end{array}$} & \multicolumn{2}{|c|}{ 1971-1983 } & \multicolumn{2}{|c|}{ 1983-1996 } & \multicolumn{2}{|c|}{ 1996-2010 } \\
\hline & & \multicolumn{2}{|c|}{$388.9 \mathrm{~mm}$} & \multicolumn{2}{|c|}{$319.7 \mathrm{~mm}$} & \multicolumn{2}{|c|}{$347 \mathrm{~mm}$} \\
\hline \multirow[t]{3}{*}{ Humidity } & Extreme humidity & $2.78 \%$ & $61.11 \%$ & $0 \%$ & $37.18 \%$ & $9.52 \%$ & $38.09 \%$ \\
\hline & High humidity & $23.61 \%$ & & $6.41 \%$ & & $7.14 \%$ & \\
\hline & Moderate humidity & $34.72 \%$ & & $30.77 \%$ & & $21.43 \%$ & \\
\hline \multirow[t]{4}{*}{ Drought } & Moderate drought & $33.33 \%$ & $38.89 \%$ & $37.18 \%$ & $62.82 \%$ & $36.9 \%$ & $61.91 \%$ \\
\hline & Severe drought & $4.17 \%$ & & $25.64 \%$ & & $23.81 \%$ & \\
\hline & Extreme drought & $1.39 \%$ & & $0 \%$ & & $1.19 \%$ & \\
\hline & Total & $100 \%$ & & $100 \%$ & & $100 \%$ & \\
\hline
\end{tabular}

NB: Values are calculated from SPI annual averages at the 6 stations (Appendix 1)

\section{Assessment of groundwater level fluctuation}

\section{Piezometric maps}

The piezometric map analysis (Fig. 10) suggests that groundwater flows towards the city of Sidi Bel Abbes, considered as a discharge zone of the aquifer, particularly given the existence of some outcrops on this part of the plain (Lake of Sidi Bel Abbes and springs in the so-called rocky point).

Moreover, the overall aspect of the maps highlights a continuous supply (drainage axes) from the Sidi Ali Ben Youb and Sidi Ali Boussidi regions, creating springs (Ain
Skhouna, Ain Mekarreg, Ain Tassi, Ain Berkouk, Ain Meddah, and Ain Anefress) supplied by the Jurassic-Cretaceous dolomite and Eocene limestone aquifers.

Also, the 1971 piezometric map identifies other drainage axes (recharge zone), namely in the region of M. Benbrahim (North-East) and Ben-Badis (South-West). This, on the one hand, can be due to the humidity prevailing in these areas over this period (Fig. 8), and, on the other hand, to the significant cumulative rainfall experienced. Indeed, many studies indicated a decrease in precipitation starting from the late 1970s (Djellouli and Daget 1993; Ketrouci et al. 2004; Khaldi 2005; Bakreti et al. 2013; Belarbi et al. 2017; Otmane 

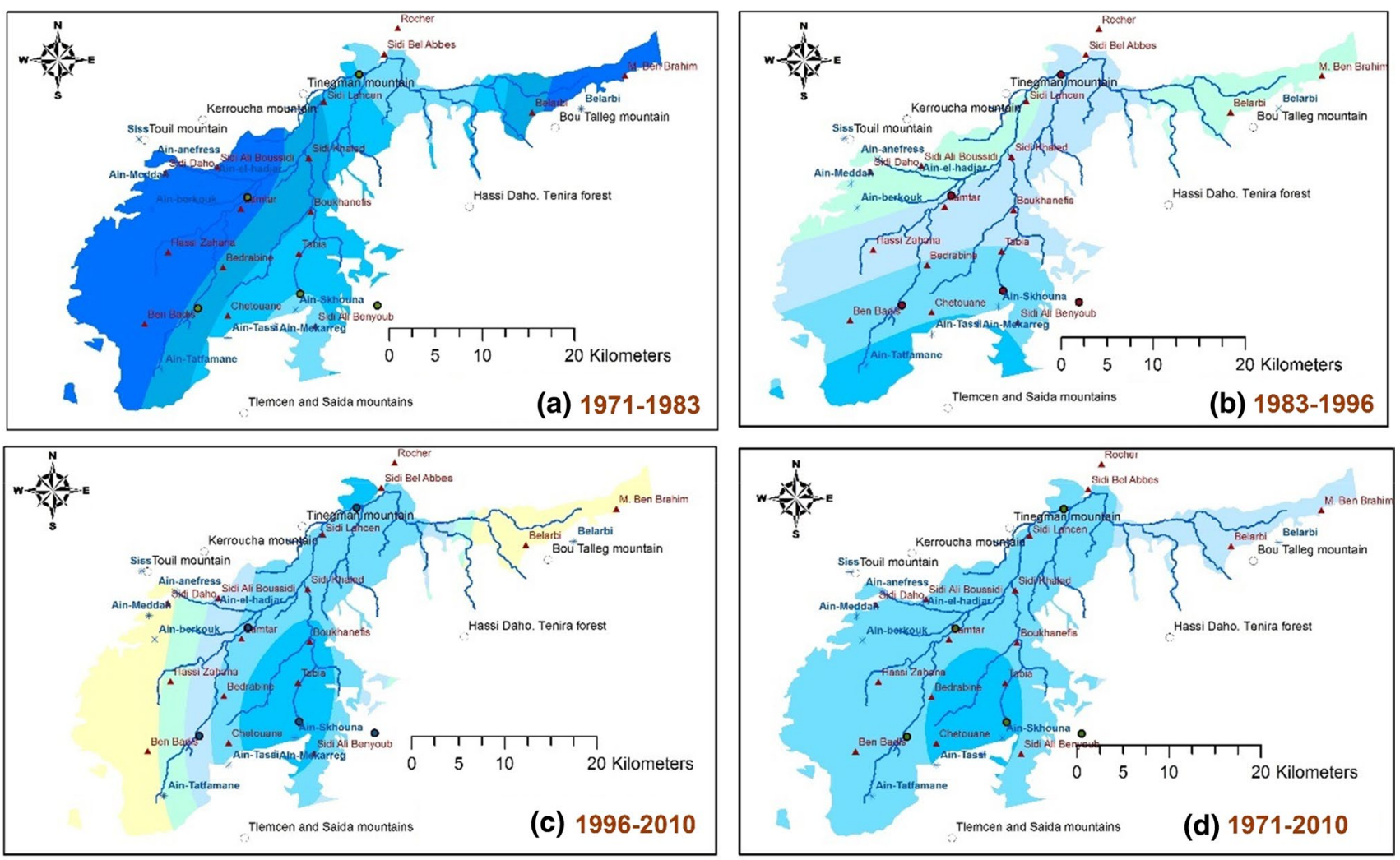

Legend

Humidity percentage

\begin{tabular}{|c|c|c|c|c|c|c|c|}
\hline 10 à $20 \%$ & 30 à $40 \%$ & 50 à $60 \%$ & 70 à $80 \%$ & * & Springs & o & Mountains \\
\hline 20 à $30 \%$ & 40 à $50 \%$ & 60 à $70 \%$ & & $\Delta$ & Towns & 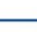 & Stream network \\
\hline
\end{tabular}

Fig. 8 Spatiotemporal distribution of humidity values over the entire observation series (1971-2010)

et al. 2018), leading to the disappearance of some drainage axes on the 1983, 1996 and 2010 maps.

\section{Spatiotemporal evolution of aquifer fluctuation}

In this section, piezometric maps (1983/1971), (1996/1983) and (2010/1996) are overlaid under a geographic information system (GIS) to identify the intersection points showing drawdowns (if the values are positive, there is groundwater recharge and vice versa). Then, with these results spatially represented (drawdown), for each period, a map of the Spatio-temporal evolution of the groundwater table fluctuation is produced (Fig. 11).

Figure 11 highlights an important drawdown of about $70 \mathrm{~m}$ in the southern part of the plain during the 1971-1983 period, and the same occurs in the northeastern part during 1983-1996, this explains why the aquifer is depleted more rapidly in the southwestern part than in the northeastern part.

However, we note an increase in the piezometric level (from 10 to $20 \mathrm{~m}$ ) in the northeast during 1971-1983, with significant stability (from 0 to $20 \mathrm{~m}$ ) in the southwest and central part of the plain, usually due to the hydraulic gradient converging towards this zone (Fig. 10). Nevertheless, during the 1983/96 period, a widespread drawdown occurred as a direct effect of severe drought and high stress on the aquifer.

The 1996-2010 period indicates an increase in aquifer levels, mainly in the area around Sidi Bel Abbes "more than $50 \mathrm{~m}$ " (discharge), at the same time, a slight drawdown is noted where the springs are concentrated (Sidi Ali Boussidi and Sidi Ali Ben Youb).

In 2010, the alluvial aquifer of Sidi Bel Abbes displayed an interesting spatial fluctuation compared to 1971. The water level increased by $50 \mathrm{~m}$ in Sidi Bel Abbes and Belarbi, with an extreme drawdown of up to $-50 \mathrm{~m}$ in the upstream regions, marked by a wall uplift (Fig. 12), and by open boundary conditions [Presence of springs]. We conclude from this that the adjacent aquifers (Jurassic-Cretaceous limestones and dolomites and Eocene limestones) contributed largely to the increase in the alluvial aquifer level. The significant drawdown recorded upstream (spring regions) is caused by the drought that affected the area during the last decades, the bowl-shaped bedrock of the aquifer, and also its overexploitation downstream. 

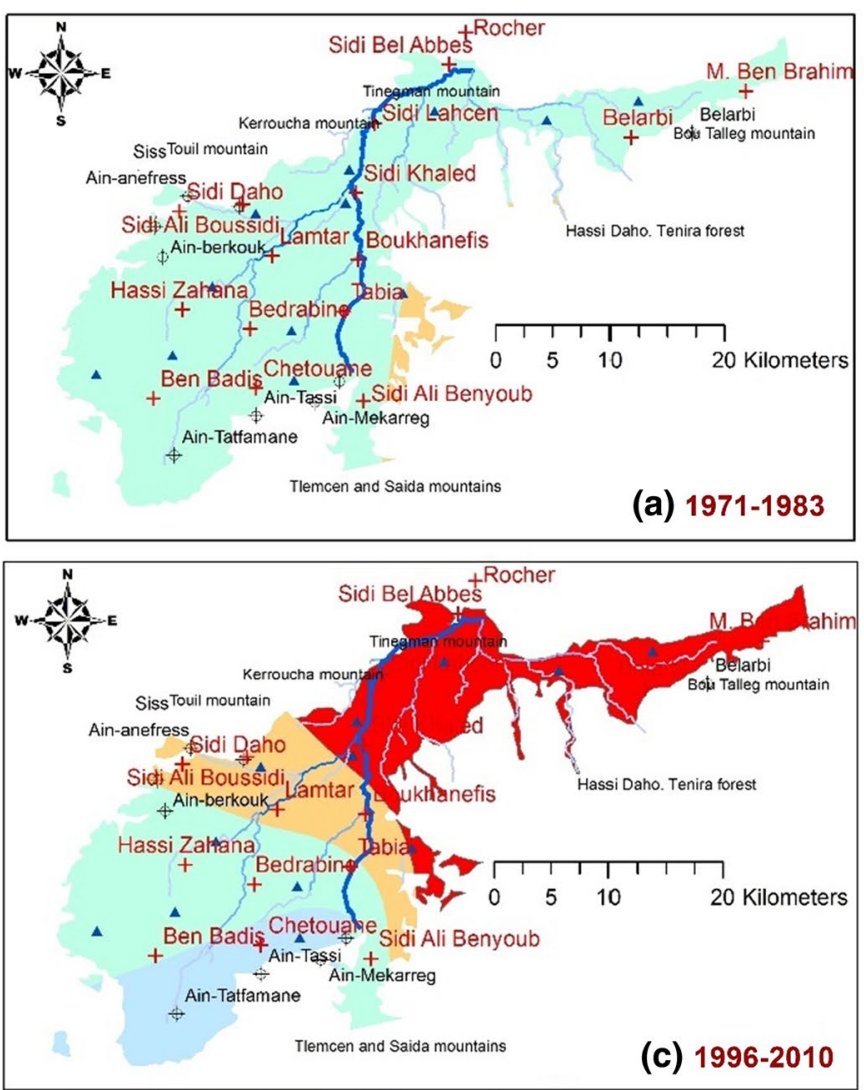

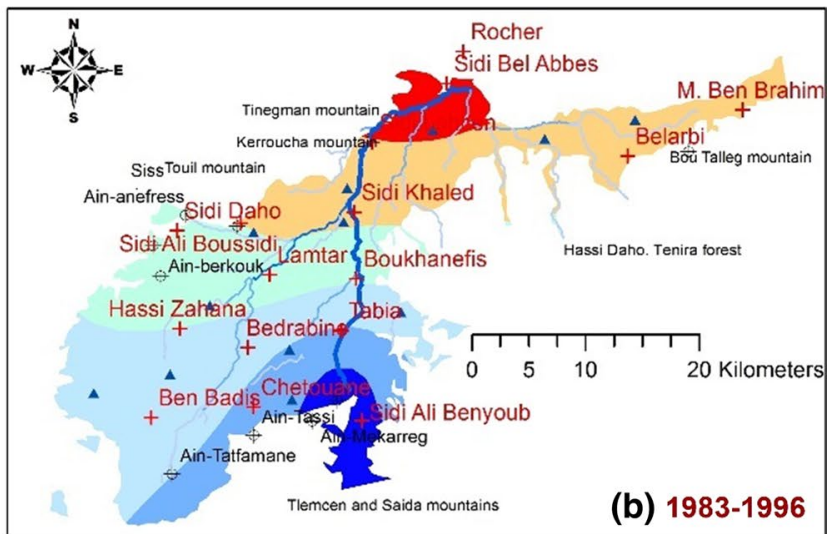

Legend

Humidity percentage

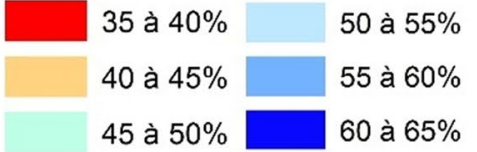

Stream network

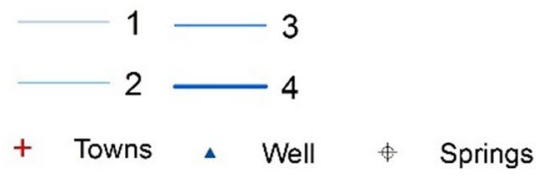

Fig. 9 Spatiotemporal distribution of humidity values for each period separately

\section{The impact of spatiotemporal variations of humidity on the aquifer's hydrodynamics}

Based on the various studies conducted on climate change in the region (Ketrouci et al. 2004; Khaldi 2005; Bakreti et al. 2013; Belarbi et al. 2017), the breaking date occurred in the 1970s, explaining humidity values of less than $50 \%$ across the entire aquifer during 1971-1983 (Figs. 9a and 11a). Consequently, the alluvial aquifer was overexploited and thus caused a significant drawdown in the area surrounding the aquifer, particularly south of the region (Ben Badis).

This hydrodynamic pattern ("water level drop" at the aquifer boundaries) is due to the bowl-shaped bedrock topography. This largely influences the groundwater flow direction (Fig. 12). In this regard, we can state that water in the middle and downstream of the aquifer is replenished consistently by the upstream water, leading to a continuous drawdown at the aquifer boundaries, particularly with the lack of precipitation, and downstream overexploitation for irrigation (Fig. 6b).

The 1983-1996 period is marked by a low humidity value, mainly in the northern part of the study area "35 to $45 \%$ " (Figs. 9b and 11b). Low cumulative annual rainfall prevailing in this area affected its recharge, resulting in significant drawdown, reaching $-50 \mathrm{~m}$. The aquifer is therefore depending on precipitation in the northern part (Belarbi-Sidi Bel Abbes).

The concentration of water points downstream of the aquifer (Fig. 6) created a large depression cone that triggered upstream gravity recharge and increased pumping demand for irrigation (Fig. 12). This explains the measurements recorded south of the aquifer despite good humidity values.

Moreover, the south-western part of the alluvial aquifer (Fig. 11) is not affected by this hydrodynamic pattern as it is not part of the main aquifer basin (Fig. 12). The water table stability in this region (Figs. $9 \mathrm{~b}$ and $11 \mathrm{~b}$ ), and its response to precipitation (humidity value), supports this.

In addition, it is important to highlight the permanent connection between the Mekerra wadi and the aquifer, explaining its stability at the wadi's boundary and especially in the center of the study area (around Bukhanefis).

The 1996-2010 period indicates a relatively low humidity value between 35 and $45 \%$ in half of the study area (Figs. 9c and 11c). While the aquifer recovered considerably, reaching $60 \mathrm{~m}$ in the north. This discordance is due to the exceptional precipitation events that occurred in the region in 2008-2009 and 2009-2010 (Fig. 13). 

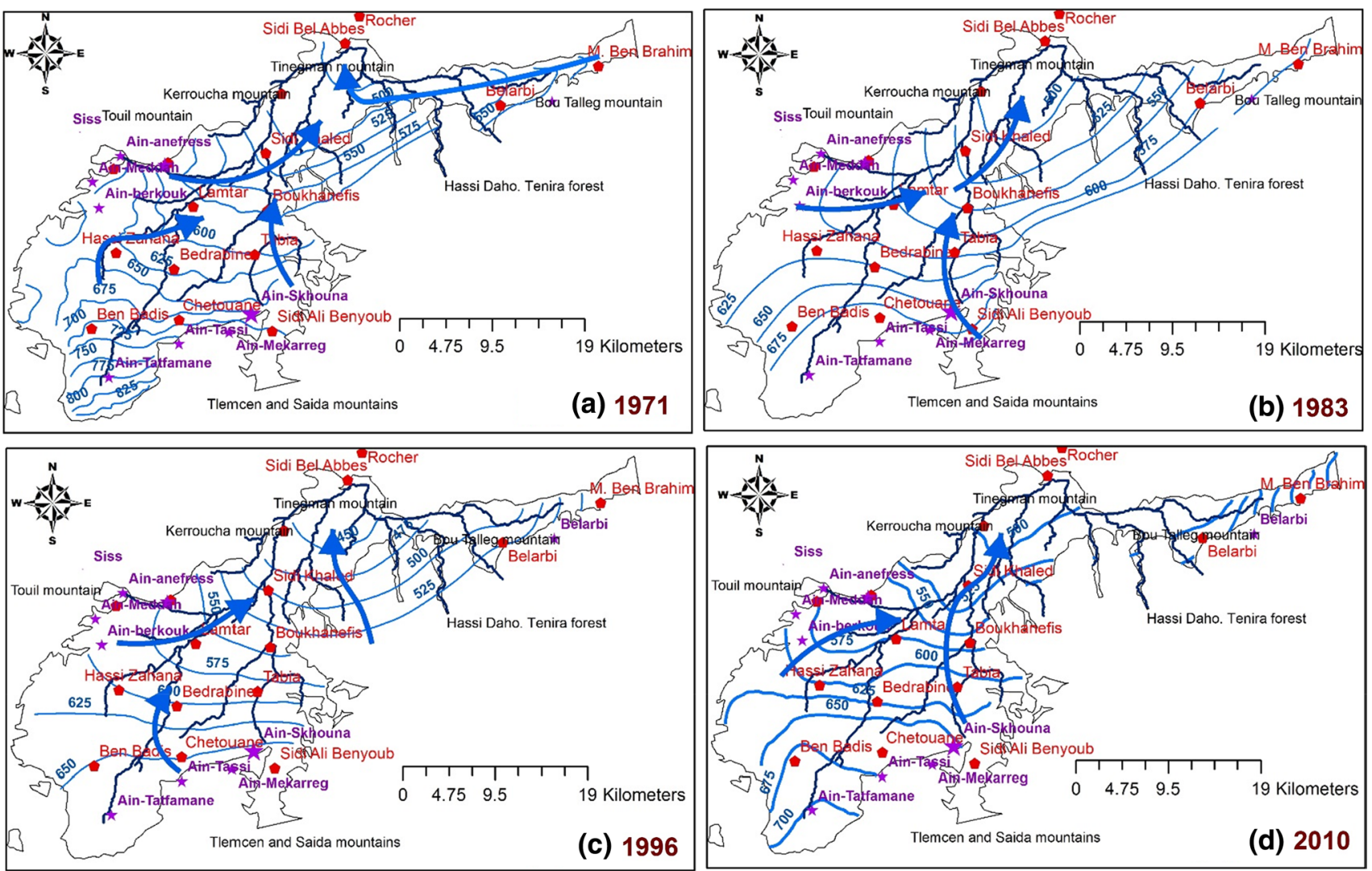

Legend
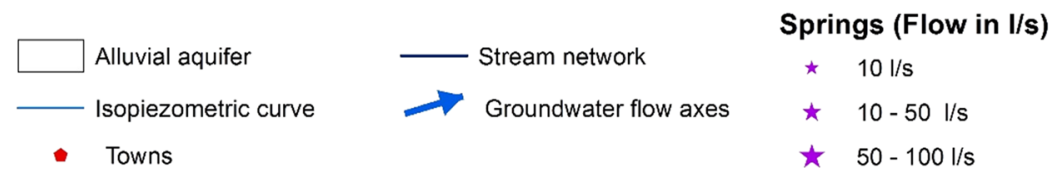

Fig. 10 Temporal evolution of the piezometric at the alluvial plain of Sidi Bel Abbes

The following figure illustrates the significance of rainfall volume in the region (2008/2009 and 2009/2010), and its classification (based on the entire observation series) varying from high to extreme humidity.

The exceptional humidity (Fig. 13) caused an increase of 5-30 m of groundwater level in the south-western part ("secondary basin"), which does not contribute to the recharge of the downstream zone (Fig. 12). Annual cumulative precipitation of about $500 \mathrm{~mm}$ is sufficient to replenish 5-30 $\mathrm{m}$ of the aquifer's water potential.

The alluvial aquifer during 1971-2010 recorded a significant increase in various areas (in the center, Sidi Bel Abbes and the south-western-northeastern boundaries), at the expense of areas marked by wall uplift (Figs. $8 \mathrm{~d}$ and 11d), thus confirming the over-exploitation of the aquifer in Sidi Bel Abbes (downstream), leading to a continuous replenishment, particularly given its transmissivity of $10^{-2} \mathrm{~m}^{2} / \mathrm{s}$ (Fig. 14).
However, the aquifer upwelling at the southwest and northeast extremities is caused by the heavy cumulative precipitation in 2009-2010. Considering the southwestern section independent from the main reservoir (Fig. 12), the northeastern edge is less transmissive (lower than $5.10^{-4} \mathrm{~m}^{2} / \mathrm{s}$ ), and thus a relatively long temporal piezometric stability is observed in this part of the aquifer (Figs. 8d and $11 \mathrm{~d}$ ).

Therefore, the discrepancy between the spatial evolution of humidity and the fluctuation of the aquifer (Figs. 8d and $11 \mathrm{~d}$ ) is due to exceptional precipitation recorded during the last 2 years of the observation period. According to Otmane et al. (2017) and Otmane et al. (2019), rainfall recorded in 2008-2009 concurs in recurrences of more than a century at all stations included in this study. 

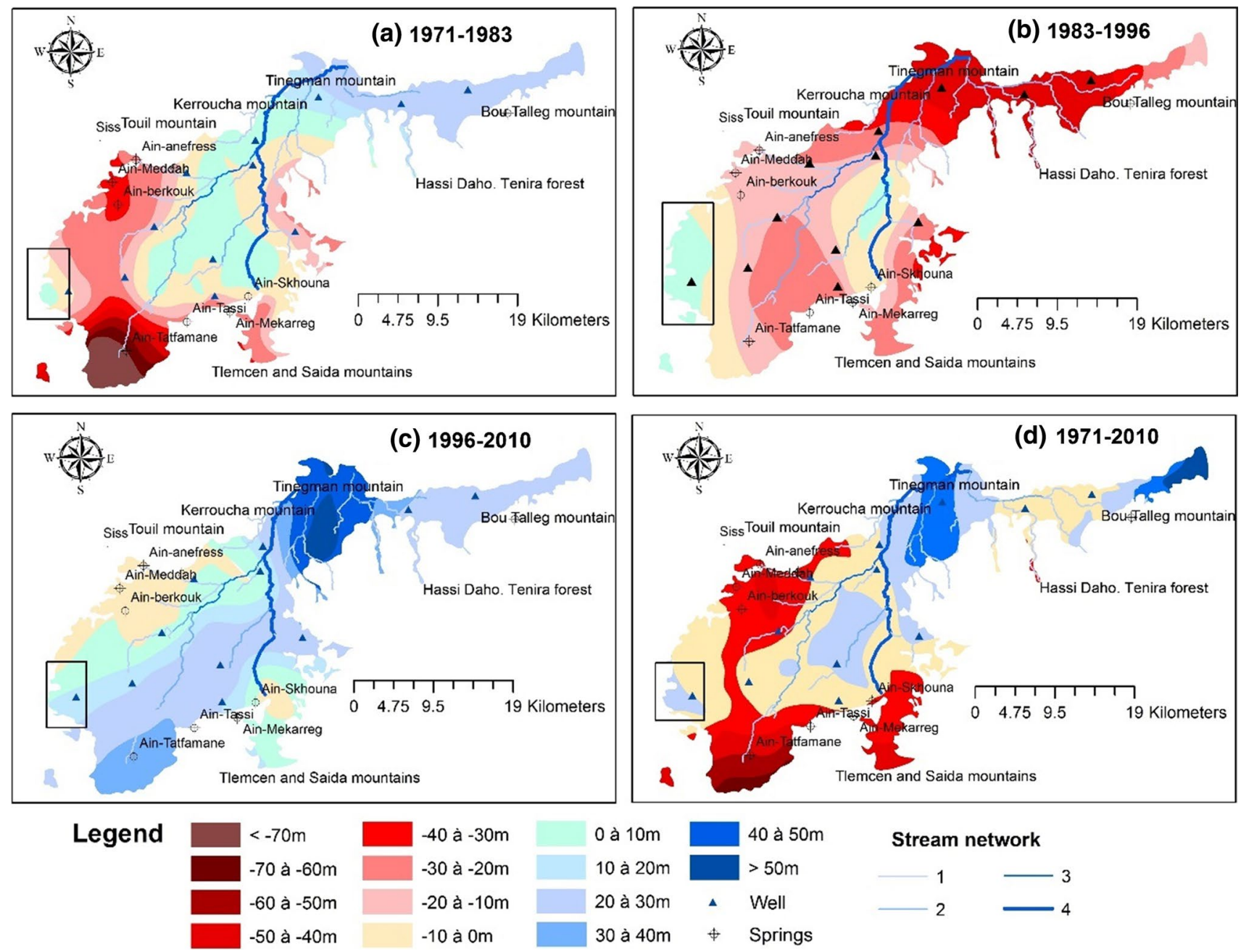

Fig. 11 Spatio-temporal evolution of groundwater fluctuation

\section{Conclusion}

This study aims to improve our understanding of the main hydrogeological characteristics and the hydrodynamic behavior of the Sidi Bel Abbes alluvial aquifer to determine its recharge pattern and evaluate the effects of overexploitation actions on its renewal. The geographical setting of the aquifer, characterized by a highly urbanized context, and surrounded by industrial and agricultural zones with vast irrigated sectors, makes it extremely exposed to local natural and anthropic risk. Today, this resource is subject to progressive anthropic pressure becoming alarming. Consequently, the current condition of this resource needs to be monitored from a quantitative point of view, to complete and update previously acquired data on flow balances. This involves the assessment of drought intensity and its risk on groundwater recharge, identification of recharge zones, and characterization of areas with high water potential.
The aquifer thickness map indicates a significant variation in alluvial recharge. The thickest layers are located in the center of the plain with the SW-NE direction. This disposition of aquifer sediment could influence transmissivity in this direction.

The map of the aquifer wall reveals its major characteristics in the downstream Mekerra watershed:

- The wall's elevation decreases from SW to NE;

- A main depression in the center, oriented SW-NE, where alluvial deposits accumulate, enabling the channel installation;

- A second depression, independent from the previous one, separated by a wall uplift following the watershed boundary.

The transmissivity map indicates that permeability increases towards the center (the area corresponding to the channel). 


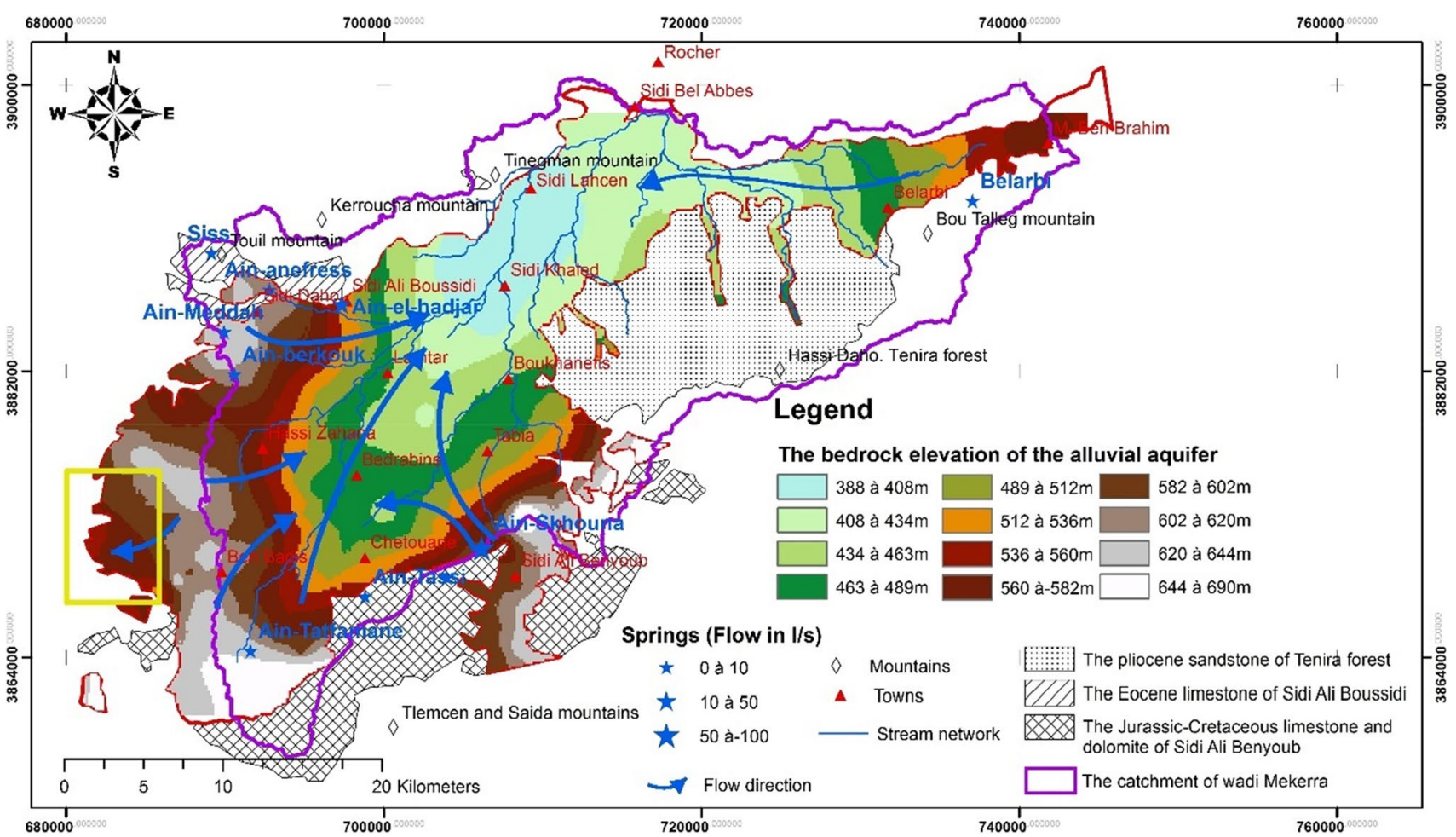

Fig. 12 Bedrock morphometry of the plio-quaternary alluvial aquifer

The plotting of the iso-piezo curves distinguishes three zones:

- A Southern zone, presenting a divergence of the currents flows expressed by a piezometric level increase due to a strong supply by the overcharge from the limestone and dolomite aquifer of the Jurassic-Cretaceous of Sidi Ali Ben Youb (overflow supply of the aquifer).

- A central zone, marked by an important drainage axis in the permeable levels (alluvium).

- A western zone, presenting a divergence of current flows supplied by the Eocene limestone aquifer of Sidi Ali Boussidi.

Analysis of the Isopiezoic curves highlights a general direction of flow from South to North. In the South and West, the isopièzes are rather spaced, while in the South and South East, the curves are closer giving higher hydraulic gradients. We also notice the draining aspect of the Wadi to the North of the aquifer and the lateral recharge zones of springs.

Temporal variations in humid conditions throughout the entire series of observations reveal a remarkable decrease. The humidity value varies between $61 \%$ (1971-1983) and $38 \%$ (1996-2010), with the occurrence of some extreme humidity cases at the end of the series, explained by the climate variability phenomenon affecting the region in recent decades.

The alluvial aquifer presents a particular hydrodynamic pattern. Indeed, decreases occur upstream (wall uplift), and the stability and/or increase (rise) downstream and in the center of the basin. This justifies the intensive overexploitation of the aquifer downstream, which induces a rapid and systematic replenishment by the water coming from upstream, resulting in a continuous drawdown upstream, especially with the lack of precipitation. Indeed, the higher the drawdown upstream, the greater the contribution of adjacent aquifers (Jurassic-Cretaceous limestones and dolomites and Eocene limestones) to supply the alluvial aquifer. Hence, such a hydrodynamic situation provides a more accurate description of drought severity (overexploitation and increase in the water points), largely decreasing the water potential of the alluvial aquifer and leading to an overflow of water to the neighboring aquifers.

Therefore, precipitation's contribution to useful reserves (groundwater that can be exploited) appears low compared to that of the neighboring aquifers, and limited during periods of high water: in other words, a lack of precipitation during this period produces a level decline that cannot be recovered by summer precipitation. A succession of drier winters leads to a hydrogeological drought situation (very low water table, drying up of springs and catchments) although the

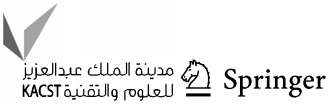



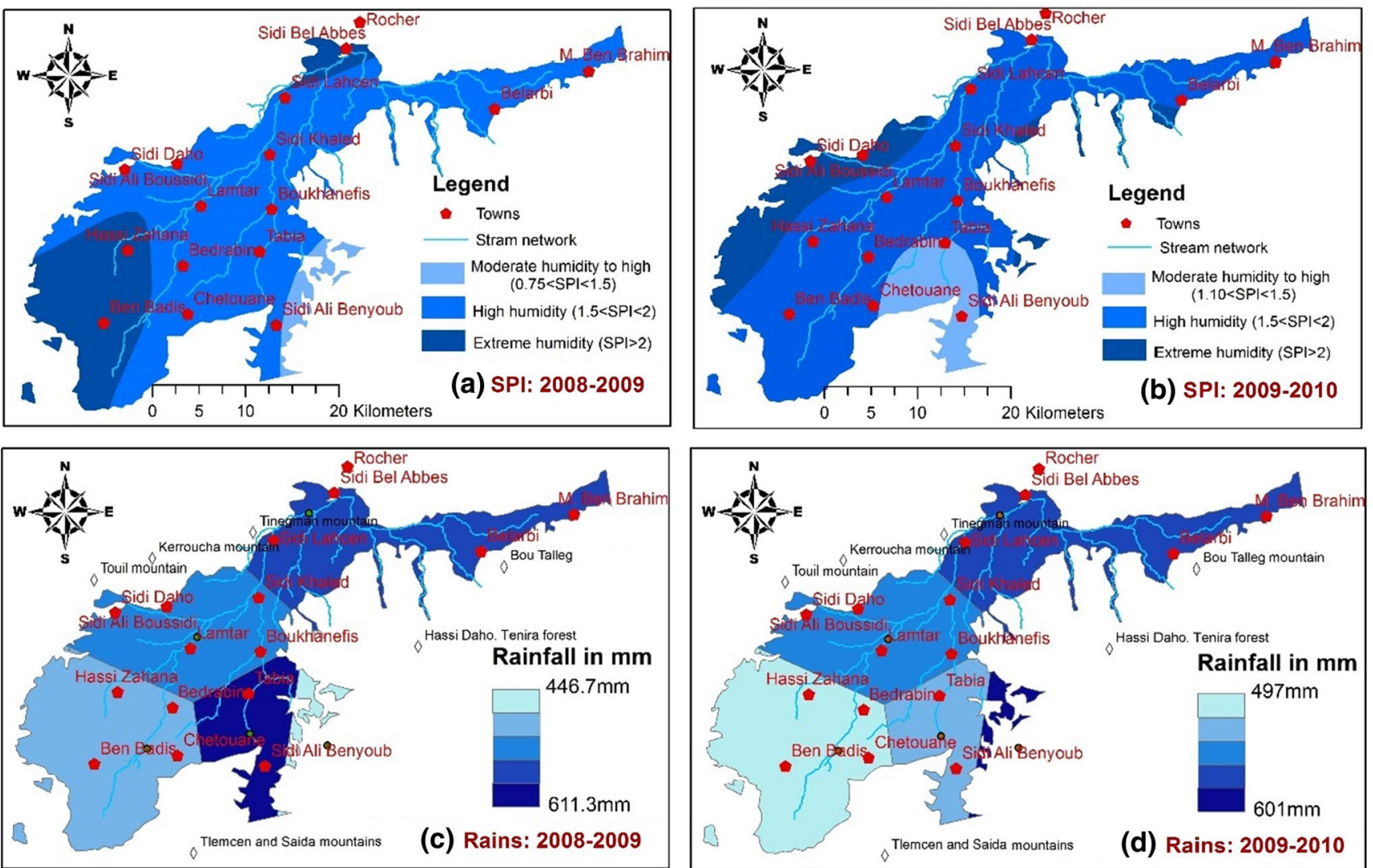

Fig. 13 a, b Spatial evolution of humidity conditions (Spline method) during 2008-2009 and 2009-2010. c, d Spatial evolution of precipitation (Thiessen polygon) during 2008-2009 and 2009-2010

total annual precipitation seems normal (as in the case of the period 1983-1996).

On the other hand, exceptional cumulative annual precipitation ( $>500 \mathrm{~mm} /$ year) contributed largely to the recharge of the aquifer and can reduce the input of neighboring aquifers (1996-2010 case).

The South-Western part of the alluvial aquifer remains unaffected by this hydrodynamic pattern, as it does not belong to the main basin. This is confirmed by the aquifer's response to humidity (precipitation). Moreover, exceptional humidity recorded at the end of the observation series involved an upwelling of 5 to $30 \mathrm{~m}$ in this part of the aquifer.

The aquifer is highly dependent on surface water for its recharge. The Wadi supplies the aquifer in its upstream and downstream parts throughout the year, especially during its flooding.

The discordance between the spatial evolution of humidity and the fluctuation of the water table is due to the hydrodynamic properties of the aquifer (main basin), very responsive to overexploitation, and the aquifer's behavior. Indeed, the aquifer instantly reacts to heavy rainfall events. Nevertheless, one notes some concordance between the spatial evolution of humidity and the groundwater fluctuation in the secondary basin (South-Western part of the groundwater table) due to limited exploitation of this part. 


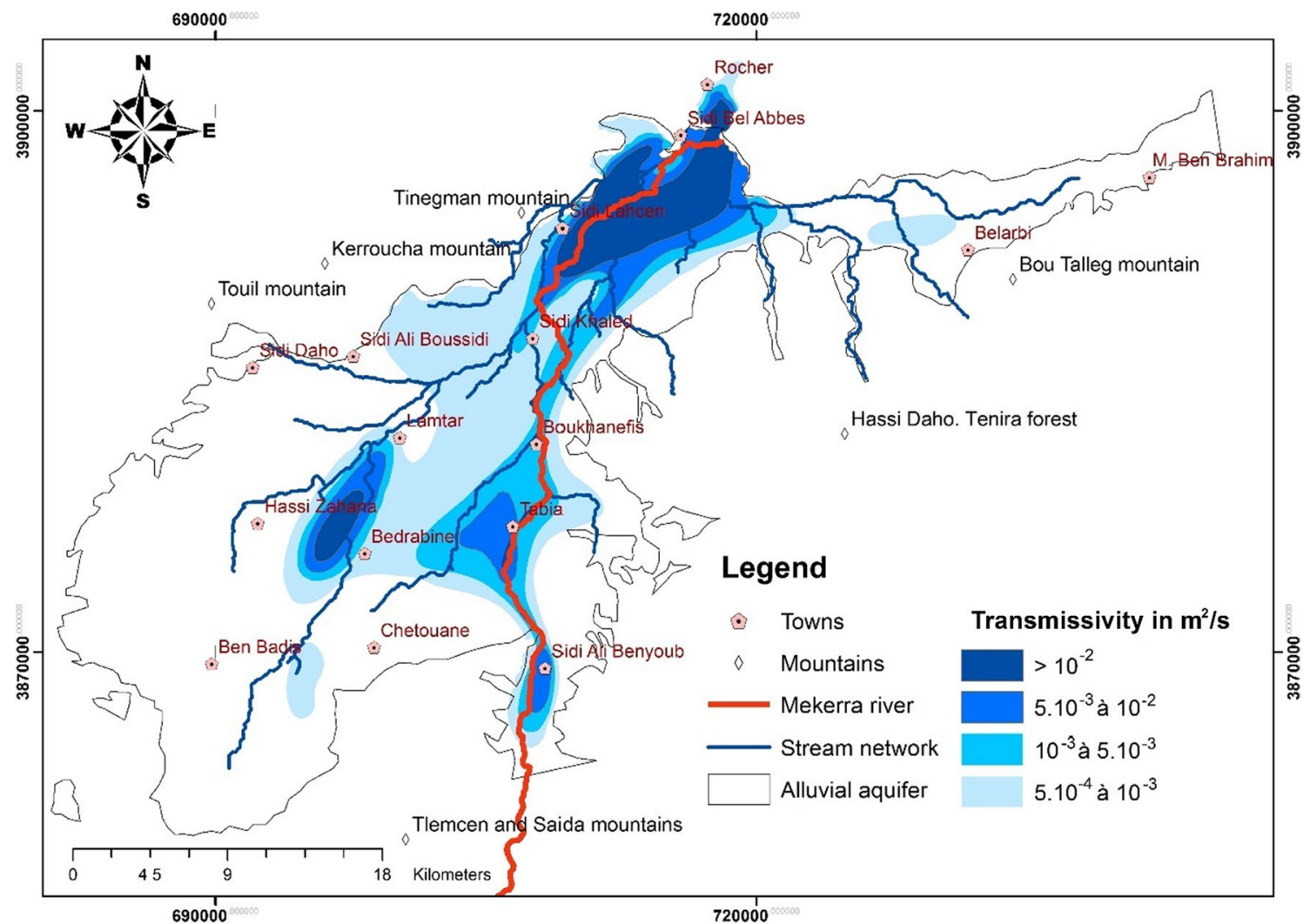

Fig. 14 Spatial evolution of transmissivity (from Sourisseau1972)

\section{Appendix 1}

\begin{tabular}{|c|c|c|c|c|c|c|c|c|}
\hline Station & & $\begin{array}{l}\text { SPI }>2 \\
\text { Humidity }\end{array}$ & $2>\mathrm{SPI}>1$ & $1>\mathrm{SPI}>0$ & $\begin{array}{l}0>\text { SPI }>-1 \\
\text { Drought }\end{array}$ & $-1>$ SPI $>-2$ & $\mathrm{SPI}<-2$ & $\mathrm{SPI}>0$ \\
\hline \multicolumn{9}{|l|}{ 1971-1983 } \\
\hline \multirow{2}{*}{$\begin{array}{l}\text { Ain Trid } \\
\qquad\left(X_{m}=437.7\right. \\
\left.S_{i}=92.1\right)\end{array}$} & $\begin{array}{l}\text { Number } \\
\text { of cases }\end{array}$ & 0 & 4 & 4 & 3 & 0 & 1 & 8 \\
\hline & $\begin{array}{l}\text { Percent- } \\
\text { age }\end{array}$ & $0.00 \%$ & $33.33 \%$ & $33.33 \%$ & $25.00 \%$ & $0.00 \%$ & $8.33 \%$ & $66.67 \%$ \\
\hline \multirow{2}{*}{$\begin{array}{r}\mathrm{S}, \mathrm{B}, \text { Abbes } \\
\left(X_{m}=334 ;\right. \\
\left.S_{i}=103.1\right)\end{array}$} & $\begin{array}{l}\text { Number } \\
\text { of cases }\end{array}$ & 0 & 3 & 3 & 5 & 1 & 0 & 6 \\
\hline & $\begin{array}{l}\text { Percent- } \\
\text { age }\end{array}$ & $0.00 \%$ & $25.00 \%$ & $25.00 \%$ & $41.67 \%$ & $8.33 \%$ & $0.00 \%$ & $50 \%$ \\
\hline \multirow{2}{*}{$\begin{array}{l}\text { Lamtar } \\
\qquad\left(X_{m}=323.7\right. \\
\left.S_{i}=107.6\right)\end{array}$} & $\begin{array}{l}\text { Number } \\
\text { of cases }\end{array}$ & 1 & 3 & 5 & 3 & 0 & 0 & 9 \\
\hline & $\begin{array}{l}\text { Percent- } \\
\text { age }\end{array}$ & $8.33 \%$ & $25 \%$ & $41.67 \%$ & $25.00 \%$ & $0.00 \%$ & $0.00 \%$ & $75 \%$ \\
\hline \multirow{2}{*}{$\begin{array}{l}\text { S, A, Ben Y } \\
\qquad\left(X_{m}=356.8\right. \\
\left.S_{i}=107.7\right)\end{array}$} & $\begin{array}{l}\text { Number } \\
\text { of cases }\end{array}$ & 0 & 1 & 5 & 6 & 0 & 0 & 6 \\
\hline & $\begin{array}{l}\text { Percent- } \\
\text { age }\end{array}$ & $0.00 \%$ & $8.33 \%$ & $41.67 \%$ & $50 \%$ & $0.00 \%$ & $0.00 \%$ & $50 \%$ \\
\hline \multirow{2}{*}{$\begin{array}{l}\text { Chetouane } \\
\qquad\left(X_{m}=341.1\right. \\
\left.S_{i}=82.3\right)\end{array}$} & $\begin{array}{l}\text { Number } \\
\text { of cases }\end{array}$ & 0 & 3 & 5 & 2 & 2 & 0 & 8 \\
\hline & $\begin{array}{l}\text { Percent- } \\
\text { age }\end{array}$ & $0.00 \%$ & $25.00 \%$ & $41.67 \%$ & $16.67 \%$ & $16.67 \%$ & $0.00 \%$ & $66.67 \%$ \\
\hline
\end{tabular}




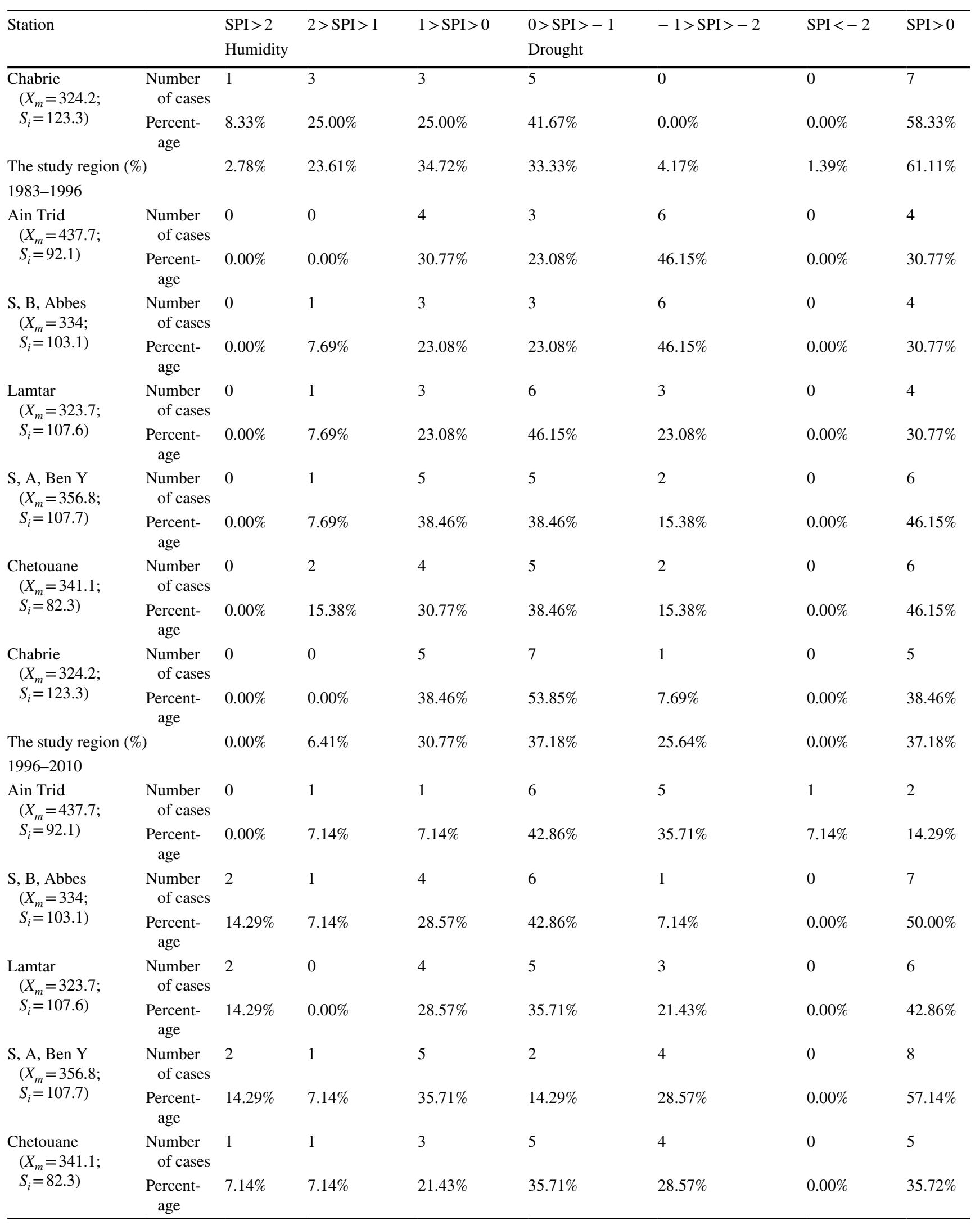




\begin{tabular}{|c|c|c|c|c|c|c|c|c|}
\hline \multicolumn{2}{|l|}{ Station } & \multicolumn{3}{|l|}{ Humidity } & \multicolumn{3}{|l|}{ Drought } & $\mathrm{SPI}>0$ \\
\hline \multirow{2}{*}{$\begin{array}{l}\text { Chabrie } \\
\qquad\left(X_{m}=324.2 ;\right. \\
\left.S_{i}=123.3\right)\end{array}$} & $\begin{array}{l}\text { Number } \\
\text { of cases }\end{array}$ & 1 & 2 & 1 & 7 & 3 & 0 & 4 \\
\hline & $\begin{array}{l}\text { Percent- } \\
\text { age }\end{array}$ & $7.14 \%$ & $14.29 \%$ & $7.14 \%$ & $50.00 \%$ & $21.43 \%$ & $0.00 \%$ & $28.57 \%$ \\
\hline \multirow{2}{*}{\multicolumn{2}{|c|}{$\begin{array}{l}\text { The study region }(\%) \\
1971-2010\end{array}$}} & $9.52 \%$ & $7.14 \%$ & $21.43 \%$ & $36.9 \%$ & $23.81 \%$ & $1.19 \%$ & $38.09 \%$ \\
\hline & & & & & & & & \\
\hline \multirow{2}{*}{$\begin{array}{l}\text { Ain Trid } \\
\qquad\left(X_{m}=437.7\right. \\
\left.S_{i}=92.1\right)\end{array}$} & $\begin{array}{l}\text { Number } \\
\text { of cases }\end{array}$ & 0 & 5 & 9 & 12 & 11 & 2 & 14 \\
\hline & $\begin{array}{l}\text { Percent- } \\
\text { age }\end{array}$ & $0.00 \%$ & $12.82 \%$ & $23.08 \%$ & $30.77 \%$ & $28.21 \%$ & $5.13 \%$ & $35.9 \%$ \\
\hline \multirow{2}{*}{$\begin{array}{r}\text { S, B, Abbes } \\
\left(X_{m}=334\right. \\
\left.S_{i}=103.1\right)\end{array}$} & $\begin{array}{l}\text { Number } \\
\text { of cases }\end{array}$ & 2 & 5 & 10 & 14 & 8 & 0 & 17 \\
\hline & $\begin{array}{l}\text { Percent- } \\
\text { age }\end{array}$ & $5.13 \%$ & $12.82 \%$ & $25.64 \%$ & $35.9 \%$ & $20.51 \%$ & $0.00 \%$ & $43.59 \%$ \\
\hline \multirow{2}{*}{$\begin{array}{l}\text { Lamtar } \\
\qquad\left(X_{m}=323.7\right. \\
\left.\quad S_{i}=107.6\right)\end{array}$} & $\begin{array}{l}\text { Number } \\
\text { of cases }\end{array}$ & 3 & 4 & 12 & 14 & 6 & 0 & 19 \\
\hline & $\begin{array}{l}\text { Percent- } \\
\text { age }\end{array}$ & $7.69 \%$ & $10.26 \%$ & $30.77 \%$ & $35.90 \%$ & $15.38 \%$ & $0.00 \%$ & $48.72 \%$ \\
\hline \multirow{2}{*}{$\begin{array}{l}\text { S, A, Ben Y } \\
\quad\left(X_{m}=356.8\right. \\
\left.\quad S_{i}=107.7\right)\end{array}$} & $\begin{array}{l}\text { Number } \\
\text { of cases }\end{array}$ & 2 & 3 & 15 & 13 & 6 & 0 & 20 \\
\hline & $\begin{array}{l}\text { Percent- } \\
\text { age }\end{array}$ & $5.13 \%$ & $7.69 \%$ & $38.46 \%$ & $33.33 \%$ & $15.38 \%$ & $0.00 \%$ & $51.28 \%$ \\
\hline \multirow{2}{*}{$\begin{array}{l}\text { Chetouane } \\
\qquad\left(X_{m}=341.1\right. \\
\left.S_{i}=82.3\right)\end{array}$} & $\begin{array}{l}\text { Number } \\
\text { of cases }\end{array}$ & 1 & 6 & 12 & 12 & 8 & 0 & 19 \\
\hline & $\begin{array}{l}\text { Percent- } \\
\text { age }\end{array}$ & $2.56 \%$ & $15.38 \%$ & $30.77 \%$ & $30.77 \%$ & $20.51 \%$ & $0.00 \%$ & $48.71 \%$ \\
\hline \multirow{2}{*}{$\begin{array}{l}\text { Chabrie } \\
\qquad\left(X_{m}=324.2\right. \\
\left.\quad S_{i}=123.3\right)\end{array}$} & $\begin{array}{l}\text { Number } \\
\text { of cases }\end{array}$ & 2 & 5 & 9 & 19 & 4 & 0 & 16 \\
\hline & $\begin{array}{l}\text { Percent- } \\
\text { age }\end{array}$ & $5.13 \%$ & $12.82 \%$ & $23.08 \%$ & $48.72 \%$ & $10.26 \%$ & $0.00 \%$ & $41.03 \%$ \\
\hline \multicolumn{2}{|c|}{ The study region $(\%)$} & $4.27 \%$ & $11.97 \%$ & $28.63 \%$ & $35.9 \%$ & $18.38 \%$ & $0.85 \%$ & $44.87 \%$ \\
\hline
\end{tabular}

NB: The SPI based on the statistical parameters $\left(X_{m}\right.$ and $\left.S_{i}\right)$ over the entire observation period (1971-2010)

\section{Appendix 2}

\begin{tabular}{|c|c|c|c|c|c|c|c|c|}
\hline Station & & $\begin{array}{l}\text { SPI }>2 \\
\text { Humidity }\end{array}$ & $2>\mathrm{SPI}>1$ & $1>\mathrm{SPI}>0$ & $\begin{array}{l}0>\mathrm{SPI}>-1 \\
\text { Drought }\end{array}$ & 1-SPI-2 & $\mathrm{SPI}<-2$ & $\mathrm{SPI}>0$ \\
\hline \multicolumn{9}{|l|}{ 1971-1983 } \\
\hline \multirow[t]{2}{*}{$\begin{array}{l}\operatorname{Lamtar}\left(X_{m}=380.2\right. \\
\left.\quad S_{i}=86.2\right)\end{array}$} & $\begin{array}{l}\text { Number of } \\
\text { cases }\end{array}$ & 0 & 2 & 4 & 4 & 2 & 0 & 6 \\
\hline & Percentage & $0.00 \%$ & $17.00 \%$ & $33.00 \%$ & $33.00 \%$ & $17.00 \%$ & $0.00 \%$ & $50.00 \%$ \\
\hline \multirow{2}{*}{$\begin{array}{l}\text { Chetouane } \\
\qquad\left(X_{m}=362.4\right. \\
\left.S_{i}=76.8\right)\end{array}$} & $\begin{array}{l}\text { Number of } \\
\text { cases }\end{array}$ & 0 & 1 & 5 & 4 & 2 & 0 & 6 \\
\hline & Percentage & $0.00 \%$ & $8.00 \%$ & $42.00 \%$ & $33.00 \%$ & $17.00 \%$ & $0.00 \%$ & $50.00 \%$ \\
\hline \multirow{2}{*}{$\begin{array}{l}\text { Chabrier } \\
\qquad\left(X_{m}=386.8\right. \\
\left.\quad S_{i}=137.9\right)\end{array}$} & $\begin{array}{l}\text { Number of } \\
\text { cases }\end{array}$ & 0 & 3 & 2 & 5 & 2 & 0 & 5 \\
\hline & Percentage & $0.00 \%$ & $25.00 \%$ & $17.00 \%$ & $42.00 \%$ & $17.00 \%$ & $0.00 \%$ & $41.66 \%$ \\
\hline \multirow{2}{*}{$\begin{array}{l}\text { S, B, Abbes } \\
\quad\left(X_{m}=368.1\right. \\
\left.\quad S_{i}=94.6\right)\end{array}$} & $\begin{array}{l}\text { Number of } \\
\text { cases }\end{array}$ & 0 & 2 & 4 & 5 & 1 & 0 & 6 \\
\hline & Percentage & $0.00 \%$ & $17.00 \%$ & $33.00 \%$ & $42.00 \%$ & $8.00 \%$ & $0.00 \%$ & $50.00 \%$ \\
\hline
\end{tabular}




\begin{tabular}{|c|c|c|c|c|c|c|c|c|}
\hline Station & & $\begin{array}{l}\text { SPI }>2 \\
\text { Humidity }\end{array}$ & $2>\mathrm{SPI}>1$ & $1>\mathrm{SPI}>0$ & $\begin{array}{l}0>\mathrm{SPI}>-1 \\
\text { Drought }\end{array}$ & 1-SPI-2 & $\mathrm{SPI}<-2$ & $\mathrm{SPI}>0$ \\
\hline \multirow{2}{*}{$\begin{array}{l}\text { S, A, Ben Y } \\
\quad\left(X_{m}=365.7\right. \\
\left.S_{i}=81.2\right)\end{array}$} & $\begin{array}{l}\text { Number of } \\
\text { cases }\end{array}$ & 0 & 1 & 5 & 3 & 3 & 0 & 6 \\
\hline & Percentage & $0.00 \%$ & $8.00 \%$ & $42.00 \%$ & $25.00 \%$ & $25.00 \%$ & $0.00 \%$ & $50.00 \%$ \\
\hline \multirow{2}{*}{$\begin{array}{l}\text { Ain-Trid } \\
\qquad\left(X_{m}=469.9\right. \\
\left.S_{i}=74.7\right)\end{array}$} & $\begin{array}{l}\text { Number of } \\
\text { cases }\end{array}$ & 0 & 2 & 5 & 1 & 3 & 1 & 7 \\
\hline & Percentage & $0.00 \%$ & $17.00 \%$ & $42.00 \%$ & $8.00 \%$ & $25.00 \%$ & $8.00 \%$ & $58.33 \%$ \\
\hline The study region (\%) & & $0.00 \%$ & $15.33 \%$ & $34.83 \%$ & $30.50 \%$ & $18.16 \%$ & $1.33 \%$ & $50.16 \%$ \\
\hline \multicolumn{9}{|l|}{ 1983-1996 } \\
\hline \multirow[t]{2}{*}{$\begin{array}{l}\operatorname{Lamtar}\left(X_{m}=285.9\right. \\
\left.\quad S_{i}=87.9\right)\end{array}$} & $\begin{array}{l}\text { Number of } \\
\text { cases }\end{array}$ & 0 & 2 & 4 & 5 & 2 & 0 & 6 \\
\hline & Percentage & $0.00 \%$ & $15.38 \%$ & $30.77 \%$ & $38.46 \%$ & $15.38 \%$ & $0.00 \%$ & $46.15 \%$ \\
\hline \multirow{2}{*}{$\begin{array}{l}\text { Chetouane } \\
\qquad\left(X_{m}=336.2\right. \\
\left.S_{i}=73.8\right)\end{array}$} & $\begin{array}{l}\text { Number of } \\
\text { cases }\end{array}$ & 0 & 2 & 5 & 4 & 2 & 0 & 7 \\
\hline & Percentage & $0.00 \%$ & $15.38 \%$ & $38.46 \%$ & $30.77 \%$ & $15.38 \%$ & $0.00 \%$ & $53.85 \%$ \\
\hline \multirow{2}{*}{$\begin{array}{l}\text { Chabrier } \\
\qquad\left(X_{m}=278.5\right. \\
\left.S_{i}=74.3\right)\end{array}$} & $\begin{array}{l}\text { Number of } \\
\text { cases }\end{array}$ & 0 & 2 & 5 & 5 & 1 & 0 & 7 \\
\hline & Percentage & $0.00 \%$ & $15.38 \%$ & $38.46 \%$ & $38.46 \%$ & $7.69 \%$ & $0.00 \%$ & $53.85 \%$ \\
\hline \multirow{2}{*}{$\begin{array}{l}\text { S, B, Abbes } \\
\quad\left(X_{m}=287.4\right. \\
\left.S_{i}=79.3\right)\end{array}$} & $\begin{array}{l}\text { Number of } \\
\text { cases }\end{array}$ & 0 & 2 & 3 & 8 & 0 & 0 & 5 \\
\hline & Percentage & $0.00 \%$ & $15.38 \%$ & $23.07 \%$ & $61.54 \%$ & $0.00 \%$ & $0.00 \%$ & $38.46 \%$ \\
\hline \multirow{2}{*}{$\begin{array}{l}\text { S, A, Ben Y } \\
\quad\left(X_{m}=339.9\right. \\
\left.\quad S_{i}=77.9\right)\end{array}$} & $\begin{array}{l}\text { Number of } \\
\text { cases }\end{array}$ & 0 & 2 & 6 & 3 & 2 & 0 & 8 \\
\hline & Percentage & $0.00 \%$ & $15.38 \%$ & $46.15 \%$ & $23.07 \%$ & $15.38 \%$ & $0.00 \%$ & $61.54 \%$ \\
\hline \multirow{2}{*}{$\begin{array}{l}\text { Ain-Trid } \\
\qquad\left(X_{m}=390.4\right. \\
\left.S_{i}=98.1\right)\end{array}$} & $\begin{array}{l}\text { Number of } \\
\text { cases }\end{array}$ & 0 & 3 & 1 & 7 & 2 & 0 & 4 \\
\hline & Percentage & $0.00 \%$ & $23.07 \%$ & $7.69 \%$ & $53.85 \%$ & $15.38 \%$ & $0.00 \%$ & $30.77 \%$ \\
\hline \multirow{2}{*}{\multicolumn{2}{|c|}{$\begin{array}{l}\text { The study region (\%) } \\
\text { 1996-2010 }\end{array}$}} & $0.00 \%$ & $16.66 \%$ & $30.76 \%$ & $41.02 \%$ & $11.53 \%$ & $0.00 \%$ & $47.42 \%$ \\
\hline & & & & & & & & \\
\hline \multirow[t]{2}{*}{$\begin{array}{l}\operatorname{Lamtar}\left(X_{m}=310.3\right. \\
\left.\quad S_{i}=125.8\right)\end{array}$} & $\begin{array}{l}\text { Number of } \\
\text { cases }\end{array}$ & 0 & 2 & 4 & 6 & 2 & 0 & 6 \\
\hline & Percentage & $0.00 \%$ & $14.28 \%$ & $28.57 \%$ & $42.86 \%$ & $14.28 \%$ & $0.00 \%$ & $42.86 \%$ \\
\hline \multirow{2}{*}{$\begin{array}{l}\text { Chetouane } \\
\qquad\left(X_{m}=327.4\right. \\
\left.S_{i}=95.7\right)\end{array}$} & $\begin{array}{l}\text { Number of } \\
\text { cases }\end{array}$ & 1 & 1 & 5 & 5 & 2 & 0 & 7 \\
\hline & Percentage & $7.14 \%$ & $7.14 \%$ & $35.71 \%$ & $35.71 \%$ & $14.28 \%$ & $0.00 \%$ & $50.00 \%$ \\
\hline \multirow[t]{2}{*}{$\begin{array}{l}\text { Chabrier }\left(X_{m}=313\right. \\
\left.\mathrm{S}_{\mathrm{i}}=132.1\right)\end{array}$} & $\begin{array}{l}\text { Number of } \\
\text { cases }\end{array}$ & 1 & 2 & 2 & 7 & 2 & 0 & 5 \\
\hline & Percentage & $7.14 \%$ & $14.28 \%$ & $14.28 \%$ & $50.00 \%$ & $14.28 \%$ & $0.00 \%$ & $35.71 \%$ \\
\hline \multirow{2}{*}{$\begin{array}{l}\mathrm{S}, \mathrm{B}, \text { Abbes } \\
\left(\mathrm{X}_{\mathrm{m}}=348.1\right. \\
\left.\mathrm{S}_{\mathrm{i}}=119.2\right)\end{array}$} & $\begin{array}{l}\text { Number of } \\
\text { cases }\end{array}$ & 1 & 1 & 3 & 8 & 1 & 0 & 5 \\
\hline & Percentage & $7.14 \%$ & $7.14 \%$ & $21.43 \%$ & $57.14 \%$ & $7.14 \%$ & $0.00 \%$ & $35.71 \%$ \\
\hline \multirow{2}{*}{$\begin{array}{r}\mathrm{S}, \mathrm{A}, \text { Ben } \mathrm{Y} \\
\left(\mathrm{X}_{\mathrm{m}}=365\right. \\
\left.\mathrm{S}_{\mathrm{i}}=149.2\right)\end{array}$} & $\begin{array}{l}\text { Number of } \\
\text { cases }\end{array}$ & 0 & 3 & 4 & 5 & 2 & 0 & 7 \\
\hline & Percentage & $0.00 \%$ & $21.43 \%$ & $28.57 \%$ & $35.71 \%$ & $14.28 \%$ & $0.00 \%$ & $50.00 \%$ \\
\hline \multirow{2}{*}{$\begin{array}{l}\text { Ain-Trid } \\
\qquad\left(X_{m}=418.4\right. \\
\left.S_{i}=109.6\right)\end{array}$} & $\begin{array}{l}\text { Number of } \\
\text { cases }\end{array}$ & 0 & 1 & 3 & 6 & 3 & 1 & 4 \\
\hline & Percentage & $0.00 \%$ & $7.14 \%$ & $21.43 \%$ & $42.86 \%$ & $21.43 \%$ & $7.14 \%$ & $28.57 \%$ \\
\hline \multicolumn{2}{|l|}{ The study region (\%) } & $3.57 \%$ & $11.9 \%$ & $25 \%$ & $44.04 \%$ & $14.28 \%$ & $1.19 \%$ & $40.47 \%$ \\
\hline
\end{tabular}

NB: The SPI based on the statistical parameters $\left(X_{m}\right.$ and $\left.S_{i}\right)$ of each period separately $(1971 / 1983,1983 / 1996$, and $1996 / 2010)$ 
Supplementary Information The online version contains supplementary material available at https://doi.org/10.1007/s13201-021-01392-7.

Acknowledgements We are thankful to ONM (Office National de Météorologie), ANRH (Agence Nationale des Ressources Hydrauliques), and DRE-Sidi Bel Abbes (Direction des Ressources en Eau) for providing us with the necessary data to conduct this study.

Funding This research received no specific grant from any funding agency in the public, commercial, or not-for-profit sectors.

Availability of data and materials All the data were provided by: The National Meteorological Office of Oran (O.N.M), the National Agency of Hydraulic Resources (A.N.R.H) and water resources department of Sidi Bel Abbes.

Code availability Software application or custom code: ArcGis 10.5, ENVI 5.3

\section{Declarations}

Conflict of interest The authors declare that they have no conflict of interest.

Open Access This article is licensed under a Creative Commons Attribution 4.0 International License, which permits use, sharing, adaptation, distribution and reproduction in any medium or format, as long as you give appropriate credit to the original author(s) and the source, provide a link to the Creative Commons licence, and indicate if changes were made. The images or other third party material in this article are included in the article's Creative Commons licence, unless indicated otherwise in a credit line to the material. If material is not included in the article's Creative Commons licence and your intended use is not permitted by statutory regulation or exceeds the permitted use, you will need to obtain permission directly from the copyright holder. To view a copy of this licence, visit http://creativecommons.org/licenses/by/4.0/.

\section{References}

Abtout L (2013) Etude hydrogéologique de la plaine de Sidi Bel Abbes: modélisation et protection de la ressource en eau. Mémoire de Magister. USTHB, Alger, p 139

Ali A, Lebel T (2009) The Sahelian standardized rainfall index revisited. Int J Climatol J R Meteorol Soc 29:1705-1714

Ardoin-Bardin S (2004) Variabilité hydroclimatique et impacts sur les ressources en eau de grands bassins hydrographiques en zone soudano-sahélienne. PhD thesis. Université Montpellier II, 351p. http://hydrologie.org/THE/ARDOIN.pdf

Ardoin-Bardin S, Dezetter A, Servat E, Mahé G, Paturel J, Dieulin C, Boyer J (2003) Analyse de la variabilité des ressources en eau en Afrique de l'Ouest sahélienne par modélisation hydrologique à grand pas de temps et d'espace [Analysis of the variability of water resources in the Africa's West Sahelian using hydrological modeling at large time and space steps]. J Eau Environ 3:5-13

Bakreti A, Braud I, Leblois E, Benali A (2013) Analyse conjointe des régimes pluviométriques et hydrologiques dans le bassin de la Tafna (Algérie Occidentale). Hydrol Sci J 58:133-151

Belarbi H, Touaibia B, Boumechra N, Amiar S, Baghli N (2017) Sécheresse et modification de la relation pluie-débit : cas du bassin versant de l'Oued Sebdou (Algérie Occidentale). Hydrol Sci J 62:124-136
Bellaredj AEM (2019) Caractérisation des principaux paramètres affectant les eaux souterraines de la plaine de Sidi Bel Abbès à l'aide du programme Visual Modflow (applications et perspectives). PhD thesis. Université Mohamed ben Ahmed, Oran, 202p

Bergaoui M, Alouini A (2002) Caractérisation de la sécheresse météorologique et hydrologique: cas du bassin versant de Siliana en Tunisie. Sci Chang Planét Sécher 12:205-213

Bodian A (2014) Characterization of the recent temporal variability of annual rainfall in Senegal (West Africa). Physio-Géo 8:297-312

Boudjadja A, Messahel M, Pauc H (2003) Ressources hydriques en Algérie du Nord. Rev Sci EauJournal Water Sci 16:285-304

Cudennec C, Leduc C, Koutsoyiannis D (2007) Dryland hydrology in Mediterranean regions-a review. Hydrol Sci J Sci Hydrol 52:1077-1087

Djellouli Y, Daget P (1993) Conséquences de la sécheresse des deux dernières décennies sur les écosystèmes naturels algériens. Publ Assoc Int Climatol 6:105-114

El Mahi A, Meddi M, Matari A, et Ketrouci K (2004) état de la pluviométrie en période de sécheresse en Algérie du nord et sa relation avec le phénomène ENSO. Acte de Colloque "Terre et Eau". (Annaba 2004), 420-423

Faye C, Sow AA, Ndong JB (2015) Étude des sècheresses pluviométriques et hydrologiques en Afrique tropicale: caractérisation et cartographie de la sècheresse par indices dans le haut bassin du fleuve Sénégal. Phys-Géo Géogr Phys Environ 9:17-35

Gain AK, Giupponi C (2015) A dynamic assessment of water scarcity risk in the Lower Brahmaputra River Basin: an integrated approach. Ecol Indic 48:120-131

Ghenim A, Megnounif A, Seddini A, Terfous A (2010) Fluctuations hydropluviométriques du bassin versant de l'oued Tafna a Béni Bahdel (Nord-Ouest algérien). Sécheresse 21:115-120

Ghenim AN, Megnounif A (2013) Ampleur de la sécheresse dans le bassin d'alimentation du barrage Meffrouche (Nord-Ouest de l'Algérie). Phys-Géo Géogr Phys Environ 7:35-49

Gherissi R (2018) Modélisation hydrologique d'un bassin versant en climat méditerranéen par l'approche conceptuelle globale. Cas de l'oued Lakhdar (ex : Chouly) (Tafna, Nord-Ouest algérien). PhD thesis. Université AbouBekr Belkaid, Tlemcen, 208p

Giddings L, Soto M, Rutherford B, Maarouf A (2005) Standardized precipitation index zones for Mexico. Atmósfera 18:33-56

Gleick PH (2003) Global freshwater resources: soft-path solutions for the 21 st century. Science 302:1524-1528

Ketrouci K, Meddi M, Matari A, El Mahi A (2004) La sècheresse dans le Nord-Ouest algérien sur les deux dernières décennies. In: Actes Du Colloque, Terre et Eau, pp. 440-443

Khaldi A (2005) Impacts de la sécheresse sur le régime des écoulements souterrains dans les massifs calcaires de l'Ouest Algérien" Monts de Tlemcen-Saida. These Dr. Univ. D'Oran Algérie, 229p

Laborde JP (2009) éléments d'hydrologie de surface. Polytech NiceSofia Antipolis, école d'ingénieurs, 198 p. https://fr.slideshare.net/ SouhilaBenkaci/elments-dhydrologie-de-surface

Lespinas F (2008) Impacts du changement climatique sur l'hydrologie des fleuves côtiers en region Languedoc-Roussillon. PhD thesis. Université de Perpignan, 305p. https://cpdp.debatpublic.fr/cpdpa quadomitia/site/DOCS/PDF/THESE_LESPINAS.PDF

Loehle C (2014) A minimal model for estimating climate sensitivity. Ecol Model 276:80-84

Loehle C, Scafetta N (2012) Climate change attribution using empirical decomposition of climatic data. ArXiv Prepr. arXiv:1206.5845

McKee TB, Doesken NJ, Kleist J (1993) The relationship of drought frequency and duration to time scales. In: Proceedings of the 8th conference on applied climatology, Boston, pp 179-183

Meddi M, Talia A, Martin C (2009) Évolution récente des conditions climatiques et des écoulements sur le bassin versant de la Macta (Nord-Ouest de l'Algérie). Phys-Géo Géogr Phys Environ 3:61-84

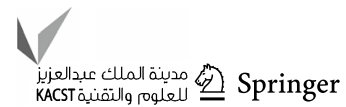


Megherfi K (2010) Contribution à la protection de la ville de Sidi Bel Abbés contre les inondations. Mémoire de Magister, UnivUSTHB, Algeria, p 158

Mirchi A, Madani K, Roos M, Watkins DW (2013) Climate change impacts on California's water resources. In: Drought in arid and semi-arid regions. Springer, pp 301-319

Nassopoulos H (2012) Les impacts du changement climatique sur les ressources en eaux en Méditerranée. PhD thesis, Université Paris-Est, 173p. https://pastel.archives-ouvertes.fr/pastel-00838 516/document

Nouaceur Z, Laignel B, Turki I (2013) Changements climatiques au Maghreb: vers des conditions plus humides et plus chaudes sur le littoral algérien? Phys-Géo Géogr Phys Environ 7:307-323

Otmane A, Baba-Hamed K, Bouanani A, Safa A (2017) Prédétermination des valeurs de crues extrêmes et contribution de la plaine de Sidi Bel-Abbès dans le bilan hydrologique du bassin versant de l'oued Mekerra. Tech Sci Méthodes 7-8:27-48

Otmane A, Baba-Hamed K, Bouanani A, Kebir L (2018) Mise en évidence de la sécheresse par l'étude de la variabilité climatique dans le bassin versant de l'oued Mekerra (Nord-Ouest algérien). Tech Sci Méthodes 9:23-37

Otmane A, Baba Hamed K, Bouanani A (2019) Apport de la variabilité spatiale des caractéristiques physiques du bassin versant dans la modélisation hydrologique et les sous-produits du bilan hydrologique: cas du bassin versant de l'aval Mekerra, Algérie. Rev Sci l'eau J Water Sci 32:117-144

Scafetta N (2012) Multi-scale harmonic model for solar and climate cyclical variation throughout the Holocene based on Jupiter-Saturn tidal frequencies plus the 11-year solar dynamo cycle. J Atmos Sol-Terr Phys 80:296-311

Sircoulon J (1976) Les données hydropluviométriques de la sécheresse récente en Afrique intertropicale. ORSTOM, Sér Hydrol 13(2):75-174

Solomon S, Manning M, Marquis M, Qin D (2007) Climate change 2007-the physical science basis: working group I contribution to the fourth assessment report of the IPCC. Cambridge University Press, Cambridge
Sönmez FK, Koemuescue AU, Erkan A, Turgu E (2005) An analysis of spatial and temporal dimension of drought vulnerability in Turkey using the standardized precipitation index. Nat Hazards $35: 243-264$

Sourisseau B (1972) Etude hydrogéologique de la plaine de Ghriss. Rapp. Agence Natl. Ressour. Hydraul Alger, Algér

Steinschneider S, McCrary R, Mearns LO, Brown C (2015) The effects of climate model similarity on probabilistic climate projections and the implications for local, risk-based adaptation planning. Geophys Res Lett 42:5014-5044

Talia A, Meddi M, Bekkoussa BS (2011) Étude de la variabilité de la pluviométrie dans les hauts plateaux et le Sahara algériens. Sci Chang Planét Sécher 22:149-158

Vörösmarty CJ, Green P, Salisbury J, Lammers RB (2000) Global water resources: vulnerability from climate change and population growth. Science 289:284-288

Vörösmarty CJ, McIntyre PB, Gessner MO, Dudgeon D, Prusevich A, Green P, Glidden S, Bunn SE, Sullivan CA, Liermann CR (2010) Global threats to human water security and river biodiversity. Nature 467:555-561

Wu H, Hayes MJ, Weiss A, Hu Q (2001) An evaluation of the standardized precipitation index, the China-Z Index and the statistical Z-Score. Int J Climatol J R Meteorol Soc 21:745-758

Xoplaki E, González-Rouco J, Luterbacher J, Wanner H (2004) Wet season Mediterranean precipitation variability: influence of largescale dynamics and trends. Clim Dyn 23:63-78

Yousfi S (2008) Hydrodynamique et modélisation de la nappe alluviale de la plaine de Sidi Bel Abbes (NO Algérie). Mémoire de Magister. Université Abou Bekr Belkaid, Tlemcen, p 91p

Publisher's Note Springer Nature remains neutral with regard to jurisdictional claims in published maps and institutional affiliations. 